\title{
Morphological and molecular assessment of Aprasia fusca and A. rostrata (Squamata: Pygopodidae), with a description of a new species from the Lake MacLeod region, Western Australia
}

\author{
Brad Maryan',4, Brian G. Bush² and Mark Adams ${ }^{3}$ \\ 1 Biologic Environmental Survey, 50B Angove Street, North Perth, Western Australia 6006, Australia. \\ Email: Lerista.2@bigpond.com \\ 2 Snakes Harmful and Harmless, 9 Birch Place, Stoneville, Western Australia 6554, Australia. \\ 3 Evolutionary Biology Unit, South Australian Museum, North Terrace, Adelaide, \\ South Australia 5000, Australia. \\ 4 Department of Terrestrial Zoology, Western Australian Museum, 49 Kew Street, Welshpool, \\ Western Australia 6106, Australia.
}

\begin{abstract}
The Australian pygopodid genus Aprasia comprises a group of small, morphologically conservative, worm-like fossorial lizards, many of which are distributed along the west coast of the continent. This study re-examines the taxonomic distinctiveness of the two most northerly occurring species in Western Australia: A. fusca and A. rostrata, which are very similar in morphology. A combined morphological and allozyme analysis revealed these two species to be conspecific with $A$. rostrata considered a senior synonym of $A$. fusca. As a consequence, we have redescribed $A$. rostrata. The allozyme analysis also revealed a new species, named here as Aprasia litorea sp. nov. This species occurs in the Lake Macleod region, well to the south of its congener, A. rostrata, and the two species are diagnosable using a conservative suite of morphological and meristic characters.
\end{abstract}

KEYWORDS: worm lizard, synonymy, Aprasia litorea sp. nov., North West Cape, Montebello Islands, Barrow Island, allozyme electrophoresis

\section{INTRODUCTION}

The taxonomy of the pygopodid gecko genus Aprasia, a group of small, worm-like fossorial lizards, is understated with exceptional species-level diversity in Western Australia (Aplin and Smith 2001: 70; Maryan et al. 2013). Based largely on allozyme data, the composite nature of some members of the A. repens species-group (as defined by Storr et al. 1990) has been revealed along with the existence of a suite of cryptic, new taxa occurring along the west coast between Geraldton and the North West Cape. One of the interesting taxonomic issues revealed, concerned the status of the most northerly-distributed species, A. rostrata Parker, 1956, on the Montebello Islands and Barrow Island, and $A$. fusca Storr, 1979, on the North West Cape, both of which have undergone several taxonomic changes since first being described.

Two specimens of Aprasia were collected on Hermite Island by Frank L. Hill in 1952 during the testing of the first British atomic weapons (Hill 1955). These were described as A. repens rostrata (Parker 1956) but subsequently elevated to full species by Kluge (1974). Storr (1979) described A. rostrata fusca from the North West Cape mainland. Storr et al. (1990) later elevated the mainland population to full species without comment. Being restricted to a single island, A. rostrata was thought to be vulnerable to extinction, based on the combined impact of anthropogenic disturbance, predation by introduced animals and residual impacts from the testing of atomic weapons (Cogger et al. 1993). This perception was further reinforced by the results of recent surveys on the islands (Burbidge et al. 2000; Richardson et al. 2006) that failed to collect additional specimens. At present, A. rostrata is listed as Vulnerable at the National level (Commonwealth: 2006 IUCN Red List), and at the state level (Schedule 1 fauna list) as a species 'that is rare or likely to become extinct' (WA Government Gazette, 9 April 2002). 
Considering the conservation status of $A$. rostrata, and particularly in view of the possible occurrence of this species on the mainland (Aplin and Smith 2001: 70), a revision of all northerly populations of Aprasia in Western Australia referable to A. fusca or A. rostrata is warranted. To resolve the taxonomic status of these two morphologically similar species, additional specimens of $A$. rostrata from the type locality were required, and in this regard, the collection of four A. rostrata from Hermite and Trimouille Islands after a 54-year gap (Maryan and Bush 2007) was pivotal in allowing these studies to be undertaken.

This paper presents the results of a combined morphological and allozyme study of all specimens of Aprasia from north of Carnarvon, referable to either $A$. fusca or $A$. rostrata. It validates the provisional assessment made by Aplin and Smith (2001: 70) that $A$. rostrata is present on the mainland and demonstrates that typical $A$. fusca is conspecific with $A$. rostrata. Finally, we demonstrate that a population of Aprasias from coastal sand dunes and adjacent sand plains west of Lake Macleod, listed by McKenzie et al. (2000: 344) as Aprasia sp. aff. fusca, is an undescribed species which we herein diagnose and name.

\section{METHODS}

\section{MORPHOLOGICAL ANALYSIS}

The eight individuals of the suspected new species from west of Lake Macleod were compared to all available specimens of $A$. fusca from the North West Cape and $A$. rostrata from the Montebello Islands and Barrow Island (Appendix and type lists in Taxonomy section). All specimens are from the collections of the Western Australian Museum, Perth (WAM). Liver samples of those specimens with tissues extracted are stored at $-70^{\circ} \mathrm{C}$ at WAM. Sex of individuals was determined by visual inspection of everted hemipenes and presence of post-cloacal spur in males, or by direct internal examination of gonads.

For the purpose of this study the following morphometric data were recorded using digital calipers to the nearest $0.1 \mathrm{~mm}$ : snout-vent length (SVL), tail length (TailL), head depth immediately behind eye (HeadD), head length from tip of snout to posterior margin of frontal scale (HeadL), head width between eye (HeadW), rostral length between anterior and posterior point of scale (RL), rostral width between lateral extremes of scale (RW), snout length from tip of snout to anterior margin of eye $(\mathrm{SnL})$ and width of the eye (EyeW). Three meristic counts were taken: number of midbody scale rows counted midway around body (Mbs), number of ventrals counted from immediately behind mental scale to vent (Vent) and number of vertebrals counted from immediately behind frontal scale to above vent (Vert). Specimens preserved in a circular or twisted position were straightened on a flat surface when measured for snout-vent and tail length. Tails were not measured if they were recently broken or obviously regenerated, as suggested by a clear break in colouration.

These morphological variables were subjected to multivariate analysis using the PRIMER v6 computer program (Clarke and Gorley 2006) with the PERMANOVA+ add-on (Anderson et al. 2008).

\section{ALLOZYME ANALYSIS}

The allozyme analysis presented here builds upon a companion study by Maryan et al. (2013), which assessed the affinities among seven of the nine species of Aprasia found in Western Australia based on allozymes. This earlier study, undertaken in 2006, included six A. fusca from several locations, but did not include $A$. rostrata, due to the unavailability of tissues at the time. The present study integrates the allozyme profiles of the 25 individuals genotyped by Maryan et al. (2013) with those obtained for an additional three $A$. fusca from the most southerly portion of its range, and for the four A. rostrata collected by Maryan and Bush (2007). Details of the specimens screened are provided in the Appendix.

Allozyme electrophoresis of liver homogenates was conducted on cellulose acetate gels as described by Richardson et al. (1986), screening the same suite of enzymes employed by Maryan et al. (2013). We also used the same analytical procedures as our previous study, namely (1) an initial, individual-based assessment to define taxa from first principles using stepwise Principal Co-ordinates (PCO) analysis, followed by (2) a taxon-based assessment of the genetic affinities among species, via the construction of a neighbourjoining tree from pairwise matrices of both the number of fixed differences and Nei's unbiased Distance. All methodological details for these two procedures are presented in Maryan et al. (2013).

\section{RESULTS}

\section{MORPHOLOGICAL ANALYSIS}

Examination of the mensural and meristic data presented in Table 1 and subjected to the PCO analysis (Figure 1) clearly differentiates the new species from $A$. rostrata, but was unable to distinguish Montebello and Barrow Island specimens from those collected on the North West Cape mainland (the latter formerly referable to $A$. fusca). Several characters separate the new species from $A$. rostrata, including the key meristic difference in Mbs and counts for the Vent and Vert scales which are considerably lower in the new taxon. Slight differences in head proportions show the new taxon to possess a shorter HeadL and corresponding SnL, combined with shallower HeadD and narrower HeadW values. The new taxon appears to attain a smaller adult size. 
TABLE 1 The mean, range, \pm one standard deviation (SD) and sample size (N) of the principal morphological measurements $(\mathrm{mm})$ and counts for $A$. rostrata and $A$. litorea.

\begin{tabular}{lcccc|cccc} 
& \multicolumn{5}{c}{ A. rostrata } & \multicolumn{5}{c}{ A. litorea } \\
& Mean & Range & SD & N & Mean & Range & SD & N \\
\hline SVL & 97.5 & $72-126$ & 11.9 & 26 & 84.8 & $60-98$ & 12.8 & 7 \\
TailL & 61.2 & $54-80$ & 18.8 & 14 & 60.7 & $40-71$ & 14.4 & 4 \\
HeadD & 1.8 & $1.2-2.4$ & 0.2 & 26 & 1.6 & $1.4-1.8$ & 0.1 & 7 \\
HeadL & 2.7 & $2.4-3.2$ & 0.2 & 26 & 2.5 & $2.3-2.7$ & 0.1 & 7 \\
HeadW & 1.9 & $1.5-2.2$ & 0.1 & 26 & 1.7 & $1.5-1.7$ & 0.0 & 7 \\
RL & 0.7 & $0.5-1.2$ & 0.1 & 26 & 0.7 & $0.6-0.7$ & 0.0 & 7 \\
RW & 0.6 & $0.5-0.7$ & 0.0 & 26 & 0.6 & $0.5-0.6$ & 0.0 & 7 \\
SnL & 1.7 & $1.5-2.0$ & 0.1 & 26 & 1.5 & $1.4-1.6$ & 0.0 & 7 \\
EyeW & 0.6 & $0.5-0.9$ & 0.0 & 26 & 0.6 & $0.5-0.8$ & 0.1 & 7 \\
Mbs & 14 & - & 0 & 26 & 12 & - & 0 & 7 \\
Vent & 183.8 & $172-192$ & 6.3 & 26 & 165.4 & $162-170$ & 3.7 & 7 \\
Vert & 179.2 & $168-190$ & 6.3 & 26 & 162.5 & $158-168$ & 4.5 & 7 \\
\hline
\end{tabular}

TABLE 2 Allozyme frequencies at all variable loci for the eight Aprasia taxa included in the allozyme study. For polymorphic loci, the frequencies of the most common allele(s) is/are expressed as percentages and shown as superscripts (allowing the frequency of the rarest alleles to be calculated by subtraction from 100\%). Sample sizes are given in brackets directly under each taxon. A dash (-) indicates this locus was not interpretable due to lack of sufficient enzyme activity. The following loci were invariant: Ak1, Gapd, Got2, Guk, Lap, Ldh, Mdh, Ndpk, Pgk, Tpi, and Ugpp.

\begin{tabular}{|c|c|c|c|c|c|c|c|c|c|}
\hline Locus & $\begin{array}{l}\text { rostrata } \\
\text { island } \\
\text { (4) }\end{array}$ & $\begin{array}{l}\text { rostrata } \\
\text { mainland } \\
\text { (6) }\end{array}$ & $\begin{array}{l}\text { litorea } \\
\text { (3) }\end{array}$ & $\begin{array}{c}\text { clairae } \\
\text { (3) }\end{array}$ & $\begin{array}{l}\text { smithi } \\
\text { (2) }\end{array}$ & $\begin{array}{l}\text { repens } \\
\text { (7) }\end{array}$ & $\begin{array}{l}\text { haroldi } \\
\text { (1) }\end{array}$ & $\begin{array}{l}\text { pulchella } \\
\text { (4) }\end{array}$ & $\begin{array}{l}\text { striolata } \\
\text { (2) }\end{array}$ \\
\hline Aconl & $\mathrm{a}$ & $\mathrm{a}^{80}, \mathrm{~b}$ & $\mathrm{a}$ & $\mathrm{c}$ & $\mathrm{d}$ & $\mathrm{c}$ & $\mathrm{c}$ & $\mathrm{a}$ & $\mathrm{a}$ \\
\hline Acon2 & $\mathrm{f}$ & $\mathrm{f}$ & $\mathrm{f}$ & $\mathrm{c}$ & $\mathrm{d}^{50}, \mathrm{~g}$ & $c^{93}, \mathrm{a}$ & $\mathrm{c}$ & $\mathrm{a}$ & $\mathrm{e}^{75}, \mathrm{~b}$ \\
\hline$A c p$ & $\mathrm{a}$ & a & a & a & a & $\mathrm{a}$ & a & $a^{75}, b$ & $\mathrm{a}$ \\
\hline Acyc & $\mathrm{a}$ & $\mathrm{a}$ & $\mathrm{a}$ & $\mathrm{a}$ & $\mathrm{a}$ & $\mathrm{a}$ & $\mathrm{a}$ & $\mathrm{b}$ & $\mathrm{b}$ \\
\hline$A k 2$ & $\mathrm{~b}$ & $\mathrm{~b}$ & b & b & $\mathrm{b}$ & $\mathrm{b}^{93}, \mathrm{a}$ & $\mathrm{b}$ & $\mathrm{b}$ & $\mathrm{b}$ \\
\hline Dia & - & - & - & - & - & - & $\mathrm{c}^{50}, \mathrm{~d}$ & $\mathrm{~b}$ & $\mathrm{a}$ \\
\hline Enol & $\mathrm{c}$ & $\mathrm{c}$ & $\mathrm{a}$ & b & $\mathrm{c}$ & $\mathrm{a}$ & a & $\mathrm{c}$ & $\mathrm{b}$ \\
\hline Est & $\mathrm{b}$ & $\mathrm{b}$ & $\mathrm{b}$ & $\mathrm{b}$ & $\mathrm{b}$ & $\mathrm{b}^{79}, \mathrm{a}$ & $\mathrm{b}$ & $\mathrm{b}$ & $\mathrm{b}$ \\
\hline Fum & $\mathrm{b}$ & $\mathrm{b}$ & b & $b^{83}, \mathrm{~d}$ & $\mathrm{~b}$ & $b^{71}, d$ & b & $b^{50}, a^{38}, c$ & $\mathrm{~b}$ \\
\hline$G d a$ & $a^{63}, b$ & a & b & $\mathrm{b}$ & $\mathrm{b}$ & $\mathrm{b}$ & - & $\mathrm{b}$ & $\mathrm{b}$ \\
\hline Glo & $\mathrm{b}$ & $\mathrm{b}$ & b & $\mathrm{b}$ & $\mathrm{a}$ & $\mathrm{b}$ & $\mathrm{b}$ & $\mathrm{b}$ & $\mathrm{b}$ \\
\hline Got1 & $\mathrm{b}$ & $\mathrm{b}^{50}, \mathrm{c}$ & $\mathrm{a}$ & b & $\mathrm{b}$ & $\mathrm{b}$ & $\mathrm{a}$ & $\mathrm{b}$ & $\mathrm{b}$ \\
\hline Gpi & $\mathrm{a}$ & $\mathrm{a}$ & $\mathrm{a}$ & $\mathrm{a}$ & $\mathrm{b}$ & $\mathrm{a}$ & $\mathrm{a}^{50}, \mathrm{~b}$ & $\mathrm{~b}^{50}, \mathrm{c}$ & $\mathrm{b}$ \\
\hline Gsr & $\mathrm{b}$ & $\mathrm{b}$ & $\mathrm{a}$ & $\mathrm{c}^{34}, \mathrm{~b}^{33}, \mathrm{a}$ & $\mathrm{a}$ & $\mathrm{a}$ & $\mathrm{a}$ & $\mathrm{c}$ & $\mathrm{c}$ \\
\hline Idh 1 & $\mathrm{~b}$ & $\mathrm{~b}$ & $\mathrm{~b}$ & $\mathrm{~b}$ & $\mathrm{~b}$ & $\mathrm{~b}$ & $\mathrm{~b}$ & $a^{63}, b$ & $\mathrm{~b}$ \\
\hline$I d h 2$ & $\mathrm{~d}$ & $\mathrm{~b}^{67}, \mathrm{c}^{17}, \mathrm{~d}$ & $\mathrm{~b}$ & $\mathrm{~b}$ & $\mathrm{a}^{50}, \mathrm{~b}$ & $\mathrm{~b}$ & - & $\mathrm{b}$ & $\mathrm{b}$ \\
\hline$M e$ & $\mathrm{e}$ & $\mathrm{e}^{83}, \mathrm{~g}$ & $\mathrm{~d}$ & $\mathrm{e}^{50}, \mathrm{f}$ & $\mathrm{b}$ & $a^{79}, e$ & $\mathrm{~b}$ & $\mathrm{f}$ & $b^{50}, \mathrm{c}$ \\
\hline$M p i$ & $\mathrm{c}$ & $\mathrm{c}$ & $\mathrm{c}$ & d & $\mathrm{c}$ & $\mathrm{c}$ & $\mathrm{c}$ & $\mathrm{a}$ & $\mathrm{b}^{75}, \mathrm{a}$ \\
\hline PepAl & b & $\mathrm{b}$ & a & $\mathrm{b}$ & $\mathrm{b}$ & $\mathrm{b}$ & - & $\mathrm{c}$ & d \\
\hline РерА2 & $\mathrm{a}$ & a & $\mathrm{c}$ & $c^{67}, b$ & $\mathrm{c}$ & $\mathrm{c}$ & $\mathrm{c}$ & $\mathrm{c}$ & $\mathrm{c}$ \\
\hline PepB & $\mathrm{a}$ & $\mathrm{c}^{58}, \mathrm{a}$ & $\mathrm{c}^{67}, \mathrm{a}$ & $\mathrm{c}$ & $\mathrm{d}$ & $\mathrm{d}^{93}, \mathrm{~b}$ & $\mathrm{c}$ & c & c \\
\hline PepC & $\mathrm{a}$ & $\mathrm{a}$ & $\mathrm{c}$ & $\mathrm{c}$ & $\mathrm{b}$ & c & $\mathrm{c}$ & $\mathrm{c}$ & $\mathrm{c}$ \\
\hline $6 P g d$ & $\mathrm{a}$ & $\mathrm{a}$ & b & $\mathrm{a}$ & $\mathrm{a}$ & $\mathrm{a}$ & $\mathrm{a}$ & $\mathrm{a}$ & $\mathrm{a}$ \\
\hline Pgm & $\mathrm{b}$ & $\mathrm{b}$ & $\mathrm{b}$ & $\mathrm{b}$ & $\mathrm{b}$ & $b^{93}, c$ & b & $\mathrm{a}$ & $\mathrm{a}$ \\
\hline$P k$ & $\mathrm{a}$ & $\mathrm{a}$ & $\mathrm{a}$ & $\mathrm{a}$ & $\mathrm{a}$ & $\mathrm{a}$ & $\mathrm{a}$ & $\mathrm{b}$ & $\mathrm{a}$ \\
\hline Sod & $\mathrm{a}$ & $\mathrm{a}$ & $\mathrm{a}$ & $\mathrm{a}$ & $\mathrm{a}$ & $\mathrm{a}$ & $\mathrm{a}$ & $\mathrm{b}$ & $\mathrm{b}$ \\
\hline Sordh & $\mathrm{b}$ & $\mathrm{b}$ & $\mathrm{c}$ & $\mathrm{c}$ & $\mathrm{a}^{50}, \mathrm{c}$ & $\mathrm{c}$ & - & $\mathrm{c}$ & $\mathrm{b}$ \\
\hline
\end{tabular}




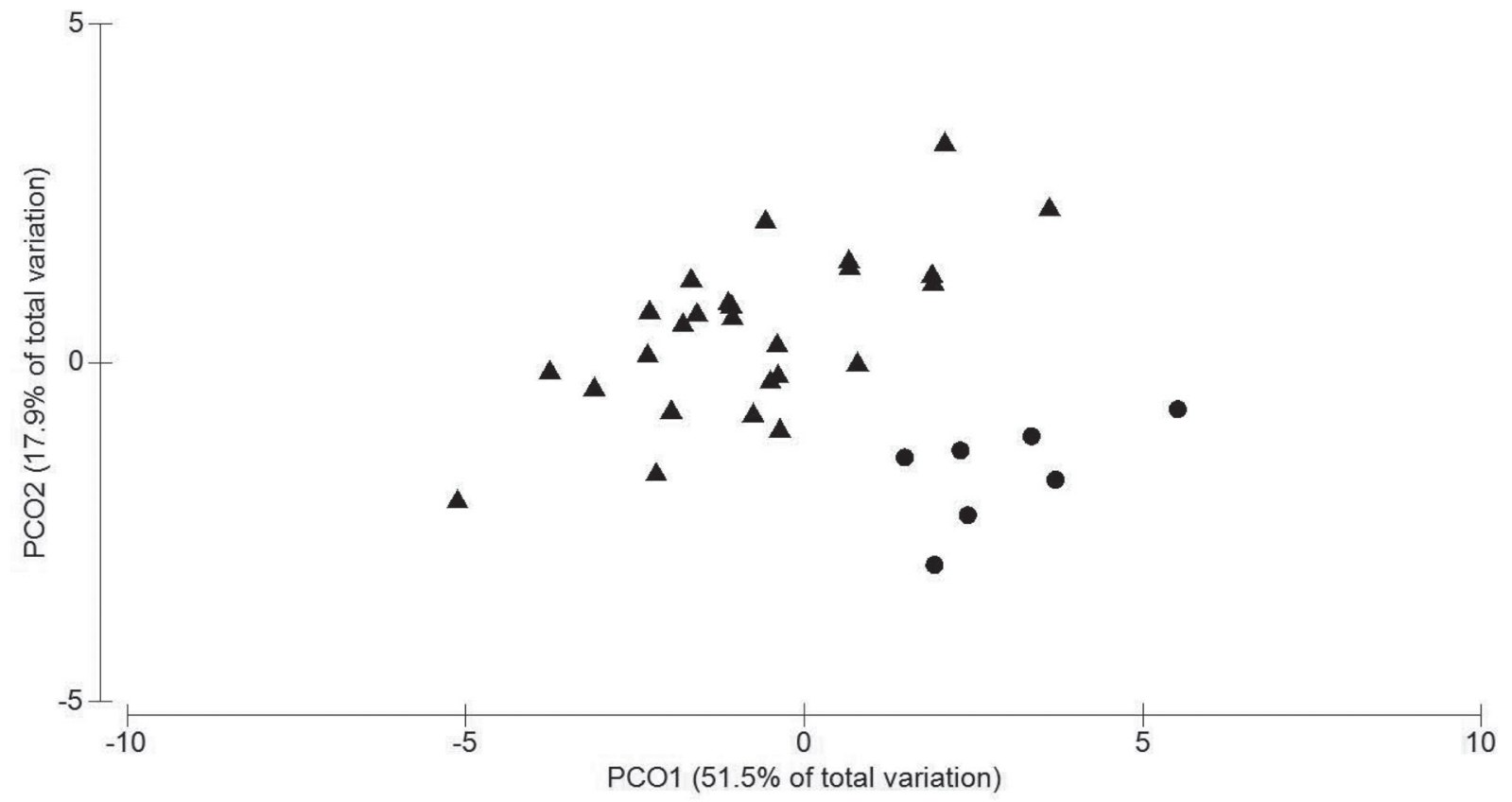

FIGURE 1 Principal Co-ordinates (PCO) analysis, based on Euclidean distances of morphological variables for A. rostrata $(\boldsymbol{\Delta})$ and $A$. litorea $(\bullet)$, with the percentage variation explained by each of the first two axes.

\section{ALLOZYME ANALYSIS}

The integrated allozyme dataset for the present study plus that of Maryan et al. (2013) comprised the genotypes of 32 individuals at 38 putative allozyme loci. These data are summarised by final taxon and locus in Table 2. An initial PCO on all individuals defined four primary groups (Figure 2a), one for each of the two species outside the $A$. repens species-group (A. pulchella and $A$. striolata), a third corresponding to all specimens north of latitude $23^{\circ} \mathrm{S}$ (referable to either A. fusca or $A$. rostrata), and the fourth, a composite group of the three southern specimens also formerly assigned to $A$. fusca, plus the other four members of the $A$. repens speciesgroup. This primary northern versus southern dichotomy within 'A. fusca' was supported by fixed differences at 10 allozyme loci, a value at the higher end of those found between other species in the group (Table 3).

A follow-up PCO on the composite 'southern' group within the $A$. repens species-group indicated that all constituent species, including $A$. litorea, were

TABLE 3 Pairwise genetic distance values between species and regional populations within the Aprasia repens speciesgroup. Lower left-hand triangle = number of loci displaying a fixed allozyme difference; upper right-hand triangle = unbiased Nei Distance.

\begin{tabular}{lccccccccc} 
& $\begin{array}{c}\text { rostrata } \\
\text { island }\end{array}$ & $\begin{array}{c}\text { rostrata } \\
\text { mainland }\end{array}$ & litorea & clairae & smithi & repens & haroldi & pulchella & striolata \\
\hline rostrata island & - & 0.04 & 0.35 & 0.31 & 0.34 & 0.32 & 0.32 & 0.58 & 0.47 \\
rostrata mainland & 0 & - & 0.31 & 0.28 & 0.34 & 0.31 & 0.27 & 0.54 & 0.44 \\
litorea & 10 & 10 & - & 0.26 & 0.36 & 0.20 & 0.13 & 0.47 & 0.42 \\
clairae & 9 & 8 & 8 & - & 0.30 & 0.11 & 0.14 & 0.37 & 0.30 \\
smithi & 11 & 11 & 11 & 9 & - & 0.22 & 0.23 & 0.50 & 0.42 \\
repens & 9 & 9 & 7 & 3 & 7 & - & 0.09 & 0.45 & 0.41 \\
haroldi & 9 & 8 & 4 & 4 & 7 & 3 & - & 0.47 & 0.34 \\
pulchella & 15 & 14 & 13 & 10 & 13 & 13 & 12 & - & 0.24 \\
striolata & 14 & 13 & 13 & 10 & 13 & 13 & 10 & 7 & - \\
\hline
\end{tabular}




\section{Dimension 1}
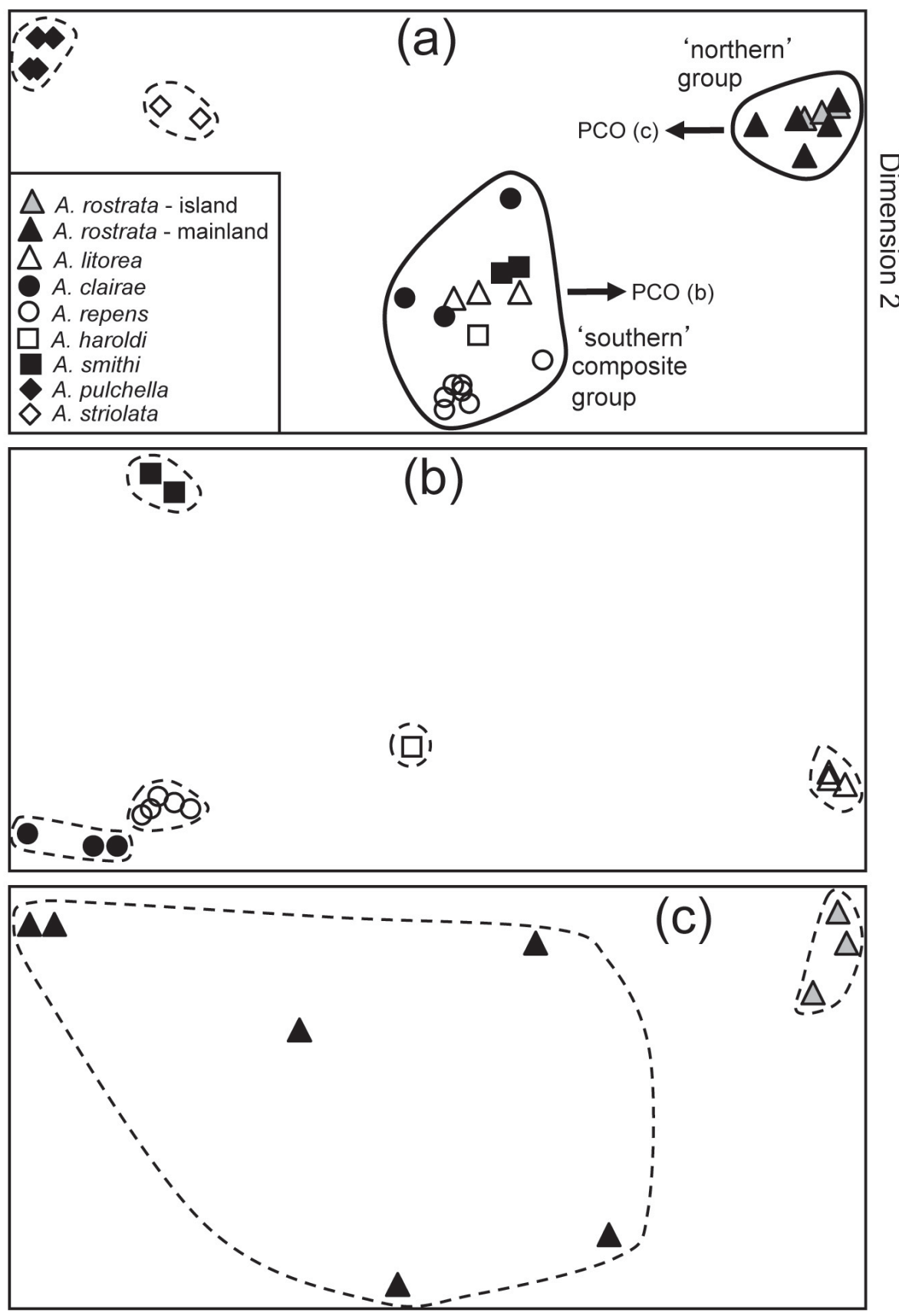

FIGURE 2 Stepwise Principal Co-ordinates analysis of the 32 Aprasia included in the extended allozyme study. Individuals are identified by a symbol depicting its morphotype. (a) Initial PCO of all specimens. Relative PCO scores have been plotted for the first and second dimensions, which individually explained $31 \%$ and $26 \%$ respectively of the total multivariate variation present. (b) Follow up PCO of individuals within the composite 'southern' cluster comprising A. litorea, A. clairae, A. repens, A. haroldi and A. smithi. These dimensions accounted for $48 \%$ and $24 \%$ respectively of the total multivariate variation present. (c) Follow up PCO of individuals within the 'northern' cluster comprising island and mainland $A$. rostrata. These dimensions accounted for $32 \%$ and $25 \%$ respectively of the total multivariate variation present. dimensions, which individually explained $31 \%$ and $26 \%$ respectively of the total multivariate variation present. (b) Follow up PCO of individuals within the composite 'southern' cluster comprising A. litorea, A. clairae, A. repens, A. haroldi and A. smithi. These dimensions accounted for $48 \%$ and $24 \%$ respectively of the total multivariate variation present. (c) Follow up PCO of individuals within the 'northern' cluster comprising island and mainland A. rostrata. These dimensions accounted for 32\% and 25\% respectively of the total multivariate variation present. 


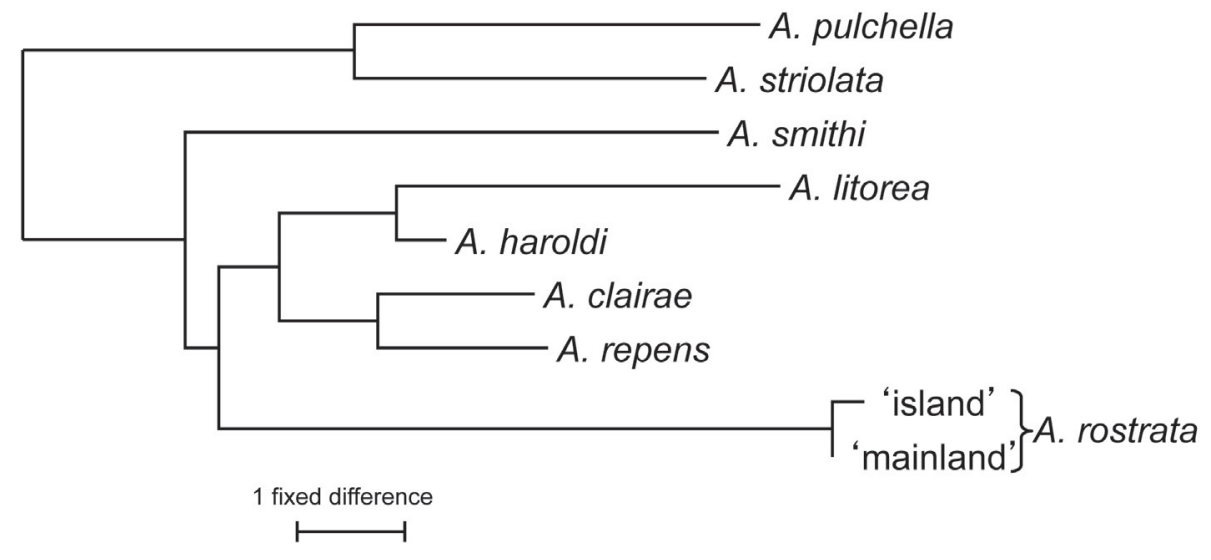

FIGURE 3 Neighbour-joining tree among eight species of Aprasia from Western Australia, based on the number of fixed differences (Table 3 ) and rooted using the two species not included in the A. repens species-group. A companion $\mathrm{NJ}$ tree, based on Nei Ds, displayed a near identical topology, and is therefore not shown.

allozymically diagnosable from one another (Figure $2 \mathrm{~b}$ ), a result further confirmed by the presence of multiple fixed differences for all pairwise comparisons (range 3-11; Table 3). In contrast, a follow-up PCO on the 'northern' group revealed only modest discrimination between island $A$. 'rostrata' and mainland $A$. 'fusca' individuals, and the two regional populations thus displayed no fixed allozyme differences and only differed by a Nei $\mathrm{D}$ value of 0.04 , well below the average between-species value for the $A$. repens species-group (mean Nei $\mathrm{D}=0.25$, range 0.09-0.36; Table 3). Thus the allozyme data are entirely consistent with these two regional populations being conspecific.

Neighbour-joining (NJ) trees among all species sampled in the extended allozyme study (Figure 3) supported the proposed monophyly of all members of the $A$. repens species-group, but did not support a sister relationship between the two most northerly members of the group, A. rostrata and A. litorea. Instead, both analysis whether for pairwise fixed differences or Nei Ds inferred that the phylogenetic affinities of $A$. litorea lie with several of the southern species, most notably $A$. haroldi.

\section{TAXONOMIC CONCLUSIONS}

Morphological and molecular analyses are fully concordant in (1) synonymising $A$. fusca and $A$. rostrata and (2) diagnosing the southern specimens previously assigned to $A$. fusca as a new species. Therefore, we redescribe $A$. rostrata from the Montebello Islands, Barrow Island and the North West Cape, and describe A. litorea of the $A$. repens species-group from the Lake Macleod region of Western Australia.

\section{TAXONOMY}

\section{Aprasia Gray, 1839}

Aprasia Gray, 1839: 331

\section{TYPE SPECIES}

Aprasia pulchella Gray, 1839, by monotypy.

\section{DIAGNOSIS}

Aprasia differs from all other pygopodid genera in possessing the following combination of character states: head scales very large, few in number; parietal scales absent; ring of ocular tissue not completely separated into distinct scales; external auditory meatus absent (small opening present beneath scale in A. aurita); scales smooth; precloacal pores absent; minute hind limb scale flaps; snout very short; body diameter very small; tail very short.

\section{INCLUDED SPECIES}

Aprasia aurita Kluge, 1974, A. clairae Maryan, How and Adams, 2013, A. haroldi Storr, 1978, A. inaurita Kluge, 1974, A. litorea sp. nov., A. parapulchella Kluge, 1974, A. picturata Smith and Henry, 1999, A. pseudopulchella Kluge, 1974, A. pulchella Gray, 1839, A. repens (Fry, 1914), A. rostrata Parker, 1956, A. smithi Storr, 1970, A. striolata Lứtken, 1863.

\section{Aprasia repens species-group}

\section{DIAGNOSIS}

As proposed by Storr et al. (1990) this group is endemic to Western Australia and currently comprises A. clairae, A. haroldi, A. litorea sp. nov., A. picturata, 
A. repens, A. rostrata and A. smithi. Compared to other Aprasia, the members of this group have a more slender body, a narrower head with a longer, more angular snout profile, and the postocular is almost always fused to the second last supralabial.

\section{Aprasia rostrata Parker, 1956}

\section{Ningaloo Worm Lizard}

Figures 5-6, 12

Aprasia repens rostrata Parker 1956: 384.

Aprasia rostrata Parker: Kluge 1974: 65-66.

Aprasia rostrata fusca Storr 1979: 136-137. New synonymy.

Aprasia fusca Storr: Storr et al. 1990: 106, 111.

\section{MATERIAL EXAMINED}

Aprasia repens rostrata

\section{Holotype}

Australia: Western Australia: male, Claret Bay, Hermite Island, Montebello Islands (20²9'S, 115²31'E) on 17 August 1952 by F.L. Hill (WAM R13861).

\section{Paratype}

Australia: Western Australia: female, as for holotype except 22 May 1952 (held in the British Museum of Natural History).

Aprasia rostrata fusca

\section{Holotype}

Australia: Western Australia: male, $3 \mathrm{~km}$ NW of Bullara $\left(22^{\circ} 40^{\prime} \mathrm{S}, 114^{\circ} 02^{\prime} \mathrm{E}\right)$ on 14 December 1978 by T.M.S. Hanlon and D. Knowles (WAM R61077).

\section{Paratypes}

Australia: Western Australia: male, female as for holotype (WAM R61078-79); male, mouth of Yardie Creek (22 $\left.20^{\prime} \mathrm{S}, 113^{\circ} 48^{\prime} \mathrm{E}\right), 8$ December 1978, G. Harold and G. Barron (WAM R61454).

\section{DIAGNOSIS}

A small (SVL up to $126 \mathrm{~mm}$ ) and very slender-bodied member of the $A$. repens species-group with 14 midbody scales, 172-192 ventral scales, 168-190 vertebral scales, five upper labials with first anteriorly fused to nasal, condition of nasal suture variably contacting prefrontal or second upper labial, postocular typically fused with fourth upper labial, and simple colouration of dark lines

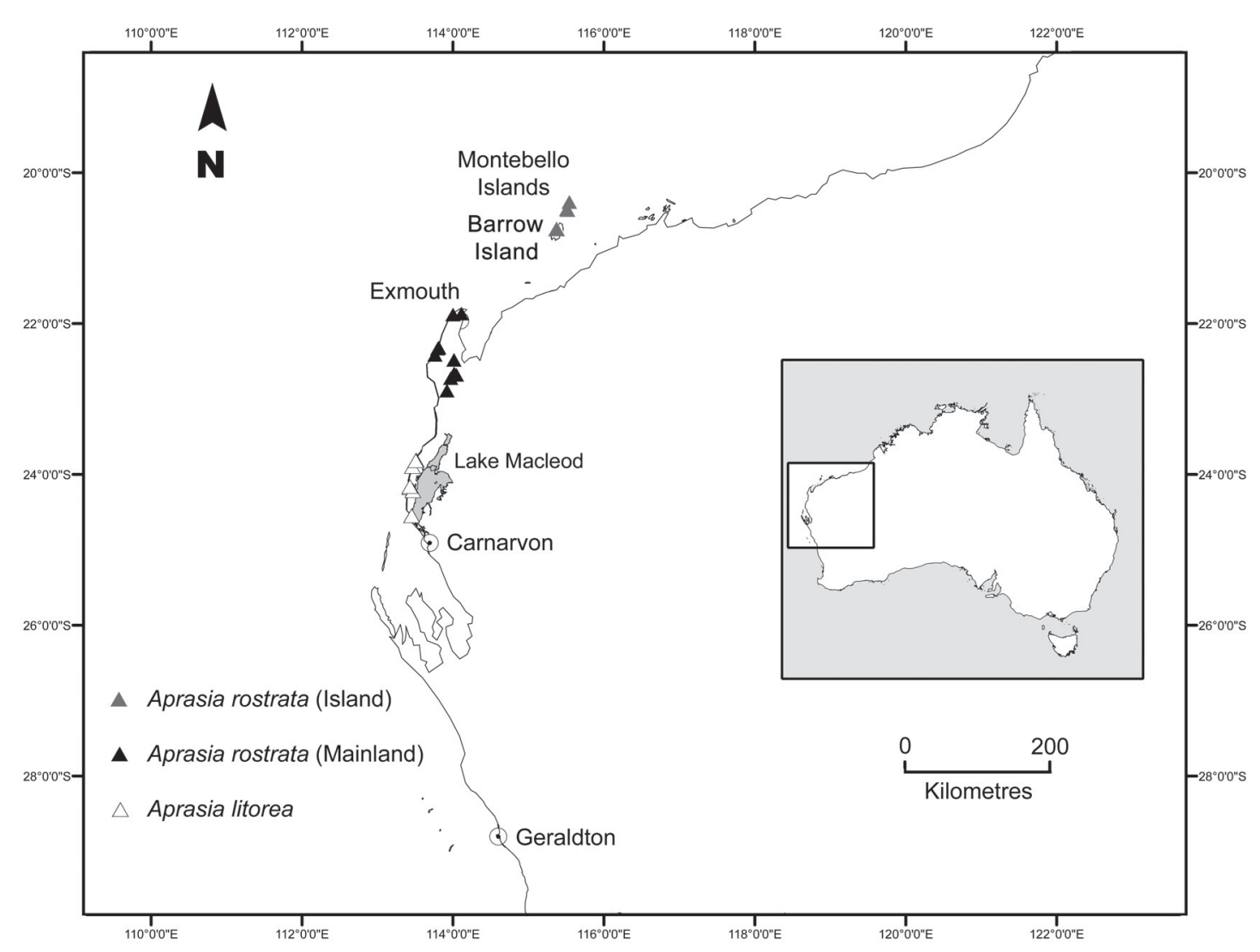

FIGURE 4 Distribution map of island and mainland populations of Aprasia rostrata and A. litorea from Western Australia. 


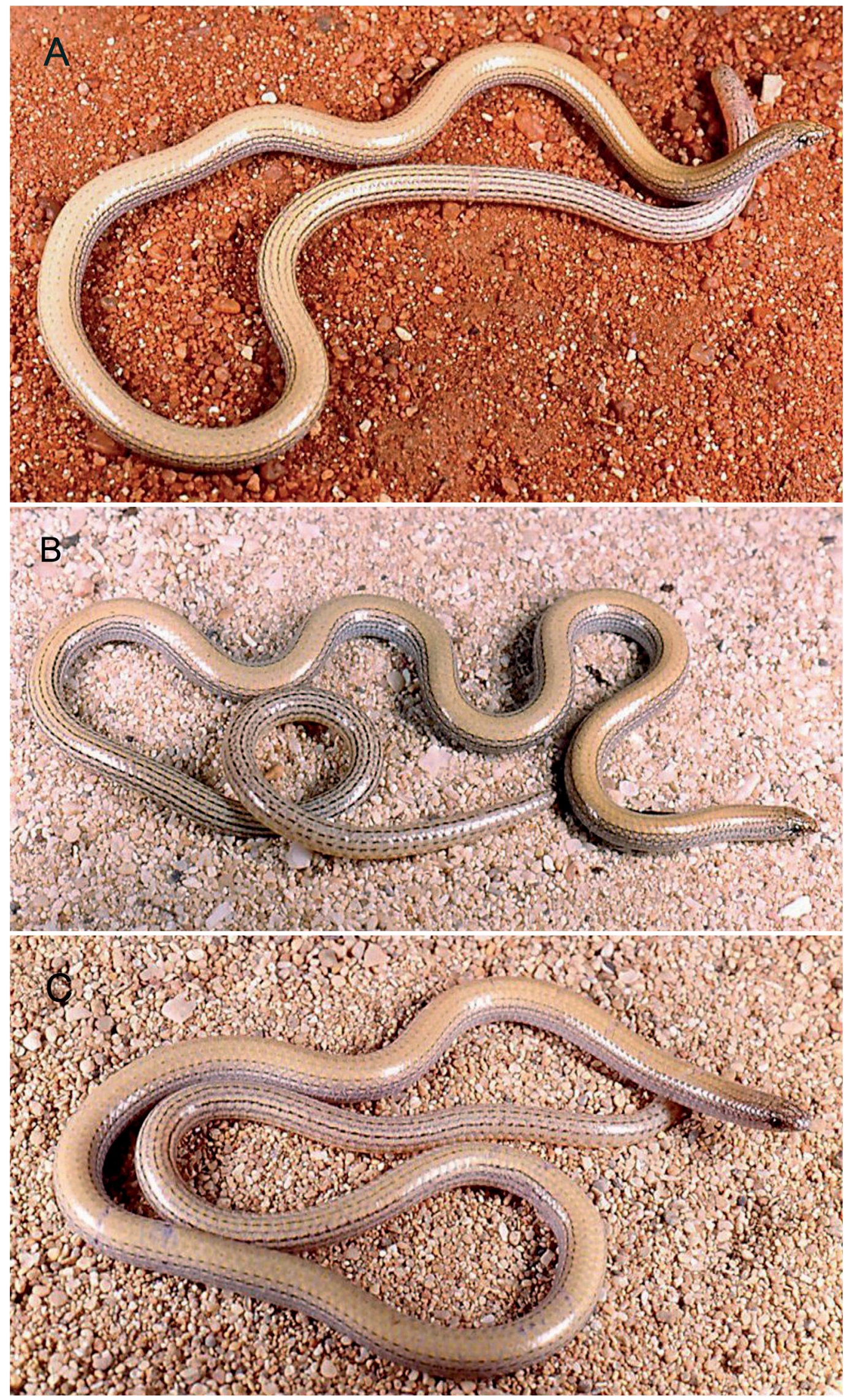

FIGURE 5 Aprasia rostrata from the inland red sand dunes near (A) Bullara Homestead, and coastal white sand dunes near (B) Yardie Homestead and (C) Hermite Island, showing the subtle colour variation in dorsal surfaces (B. Maryan). 
or streaks on a cream to light brown dorsum, and with a lightly to heavily flecked ventral surface.

\section{REDESCRIPTION}

General form of head and details of scalation illustrated in Parker (1956: 384) and Storr et al. (1990: 106, 111).

Head narrow, with long strongly projecting snout, moderately angular in profile, forming very distinct undershot lower jaw; eyes distinctly large on head positioned above third upper labial; large rostral scale clearly visible from above penetrating very deeply (e.g. WAM R142340) or moderately (e.g. WAM R153830) within nasals posteriorly, leading edge of rostral acutely angular but not sharp-edged, in most individuals (e.g. WAM R116672, WAM R142340, WAM R151727 and WAM R153828-29) the forward projection of the rostral scale forms a weak 'trilobed' appearance in dorsal view; nasal anteriorly fused and forming suture with first upper labial, origin of nasal suture is variable (see variation below) forming short contact between prefrontal and first upper labial or between nasal and second upper labial, nostril and nasal suture not visible from above; prefrontals large, forming a medial suture and in broad contact with second upper labial; 1 small preocular in broad contact with second upper labial and in short contact with third upper labial; 1 large supraocular in contact with preocular; upper labials 5; second higher than third with relatively equal width, fourth typically fused to postocular and fifth the smallest; frontal hexagonal, slightly longer than wide and rounded posteriorly.

\section{Colouration}

In life (Figure 5), head cream to light brown, weakly to strongly variegated with dark brown to black. Dorsal surface cream to light brown with four longitudinal dark brown lines (passing through centres of paravertebral and laterodorsal scales), the central pair being weak or virtually absent (e.g. WAM R116651, WAM R153828 and WAM R153830) to very strong and continuous (e.g. WAM R151726). The outermost lines of laterodorsal streaks are more continuous and clearly demarcated from a whitish to silvery-grey lateral surface, broadly edged and centrally streaked with dark brown to black. Ventral surface including under head, lightly or densely flecked with grey to dark brown. In some individuals (e.g. WAM R130221) the flecking is very dark and almost uniformly black. Tails creamish to pale yellow with multiple $(<10)$ brown lines, in some individuals (e.g. WAM R153828) the lines are absent on dorsal surface of tail. Regenerated portion light yellow clouded with grey.

In preservative, the dorsal surfaces of the more lightly brown individuals from inland localities distant from the coast become paler. Individuals from coastal localities retain their cream dorsal surfaces. The dark pigment on the lateral and ventral surfaces, including the lines of streaks along tail, is more prominent.

\section{Details of holotype}

Kluge (1974: 65-66) provides a detailed description of the $A$. rostrata holotype with accompanying illustration of the left lateral view of head showing extra postnasal and postorbital scales (Figure 30: 64), a condition not observed in any other Aprasia and described as 'freakish' by Storr (1979: 137) who considered the 'postorbital' scale as a free postocular (Storr et al. 1990: 111).

Measurements in mm (this study). SVL - 94, TailL 65 regenerated ( $69 \%$ of SVL), HeadD - 1.7, HeadL - 2.6, HeadW - 2.1, RL - 1.2, RW - 0.7, SnL - 1.5, EyeW 0.6 , Mbs - 14, Vent - 174, Vert - 160 .

After more than 50 years in preservative (Figure 6), the holotype is brownish on the dorsal surface with a light brown ventral surface without any discernible pattern.

\section{VARIATION}

Table 1 presents the ranges of the characters counted and measured for $A$. rostrata. The nature of the nasal suture originating from either the prefrontal or second upper labial is variable in $A$. rostrata as follows: suture contacts prefrontal on both sides in WAM R116672, WAM R116914, WAM R141583, WAM R151725 and WAM R153829-30; suture contacts second upper labial on both sides in WAM R61079, WAM R61454, WAM R74951, WAM R110662, WAM R116651, WAM R130221, WAM R142340, WAM R142359, WAM R151726-27, WAM R153828, WAM R165984 and WAM 165986; both conditions recorded on opposing sides in WAM R61077-78, WAM R116882, WAM R153827, WAM R165985 and WAM R165987. In specimens from the Montebello Islands, WAM R165984 has a 'postorbital' scale on right side only, WAM R165986 on both sides and WAM R165987 on left side only. In the specimen from Barrow Island, WAM R173456 the nasal suture contacts an extra postnasal scale on both sides.

\section{ETYMOLOGY}

Parker (1956) provided no derivation of name; however the specific name is presumably from the Latin adjective rostratus, meaning beaked, referring to the protrusive snout of the species.

\section{DISTRIBUTION}

Aprasia rostrata is known from Hermite and Trimouille Islands in the Montebello Islands and Barrow Island off the Pilbara coast and on the North West Cape, extending south to Yardie Creek and Learmonth Air Weapons Range and inland to Bullara Station (Figure 4). The islands are designated Class 'A' Nature Reserves. Further surveys are required at optimum times on other Montebello Islands to determine whether this species is distributed more widely in the area. On the North West Cape, very little protection is given to areas outside the Cape Range National Park. 


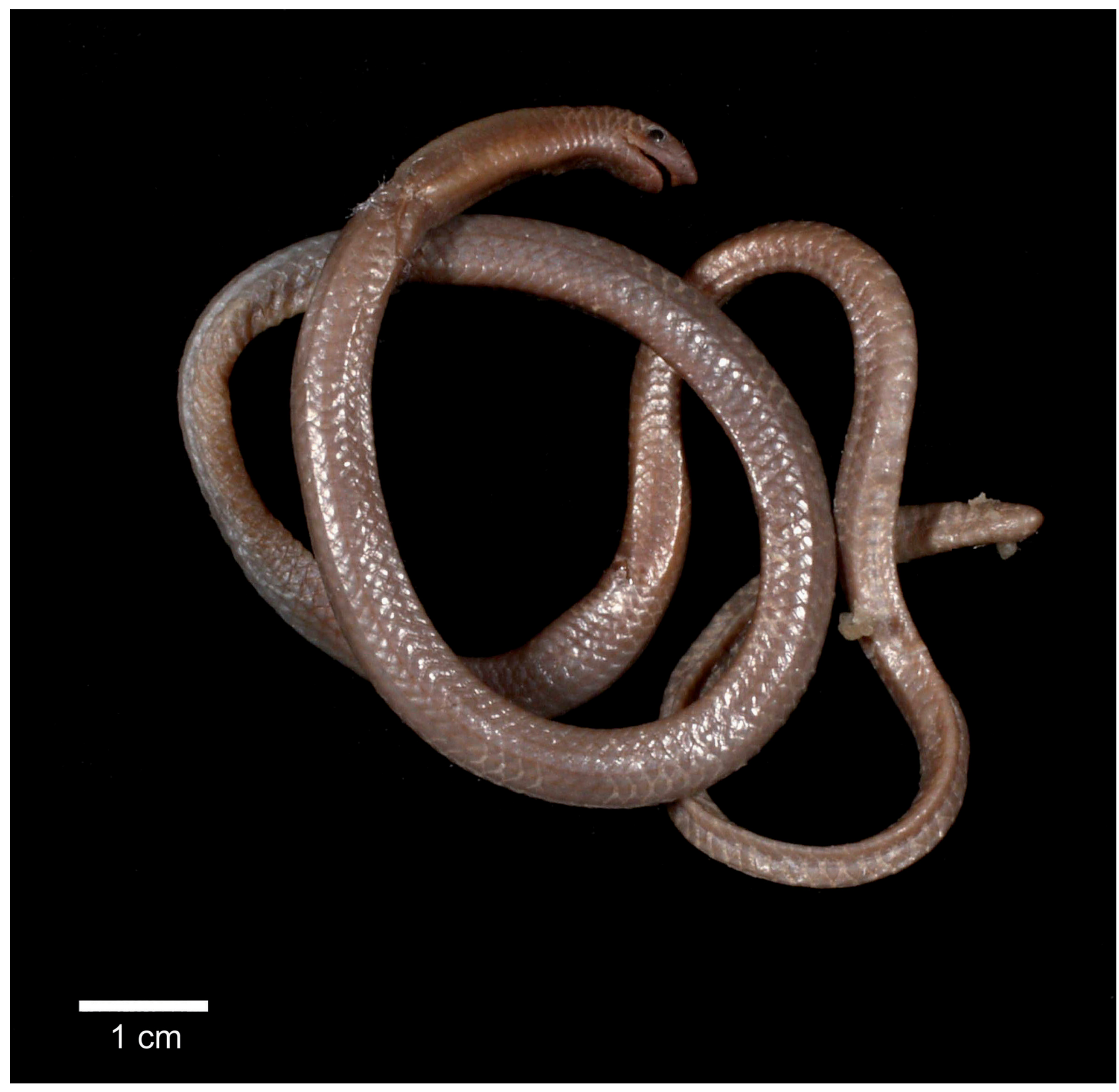

FIGURE 6 Preserved holotype of Aprasia rostrata (WAM R13861).

\section{HABITAT}

Aprasia rostrata appears to be widespread on the North West Cape as suggested by Storr and Hanlon (1980) occupying sandy habitats such as white sand dunes on the coast and inland on red Triodia-covered sand dunes (Figure 7). Similarly, on the Montebello Islands, Hermite and Trimouille, the species has been collected in low white sand dunes vegetated with Acacia coriacea over Spinifex and other low shrubs (Maryan and Bush 2007). The single individual collected on Barrow Island also came from secondary white sand dunes on a limestone pavement with Spinifex longifolius (R. Teale, pers. comm.). The species has been mainly raked (using a 3-prong cultivator) from sand hillocks stabilised by vegetation on dunes, beneath decaying stumps and logs embedded in the sand, leaflitter and occasionally exfoliated limestone slabs. Invariably, the stumps and logs have living ant colonies associated with them (B. Maryan and B.G. Bush pers. obs.).

\section{COMPARISONS WITH OTHER SPECIES}

Aprasia rostrata will be compared first with its nearest geographical congeners, A. haroldi, A. clairae and $A$. repens, the species with which it is most similar to in general aspects of body size, colouration and scalation, then with each of the other allopatric distant species with which it shares important characters.

Aprasia rostrata differs from $A$. haroldi in having 5 upper labials (v. 4), postocular fused to fourth upper labial (v. fused to third) and third upper labial 


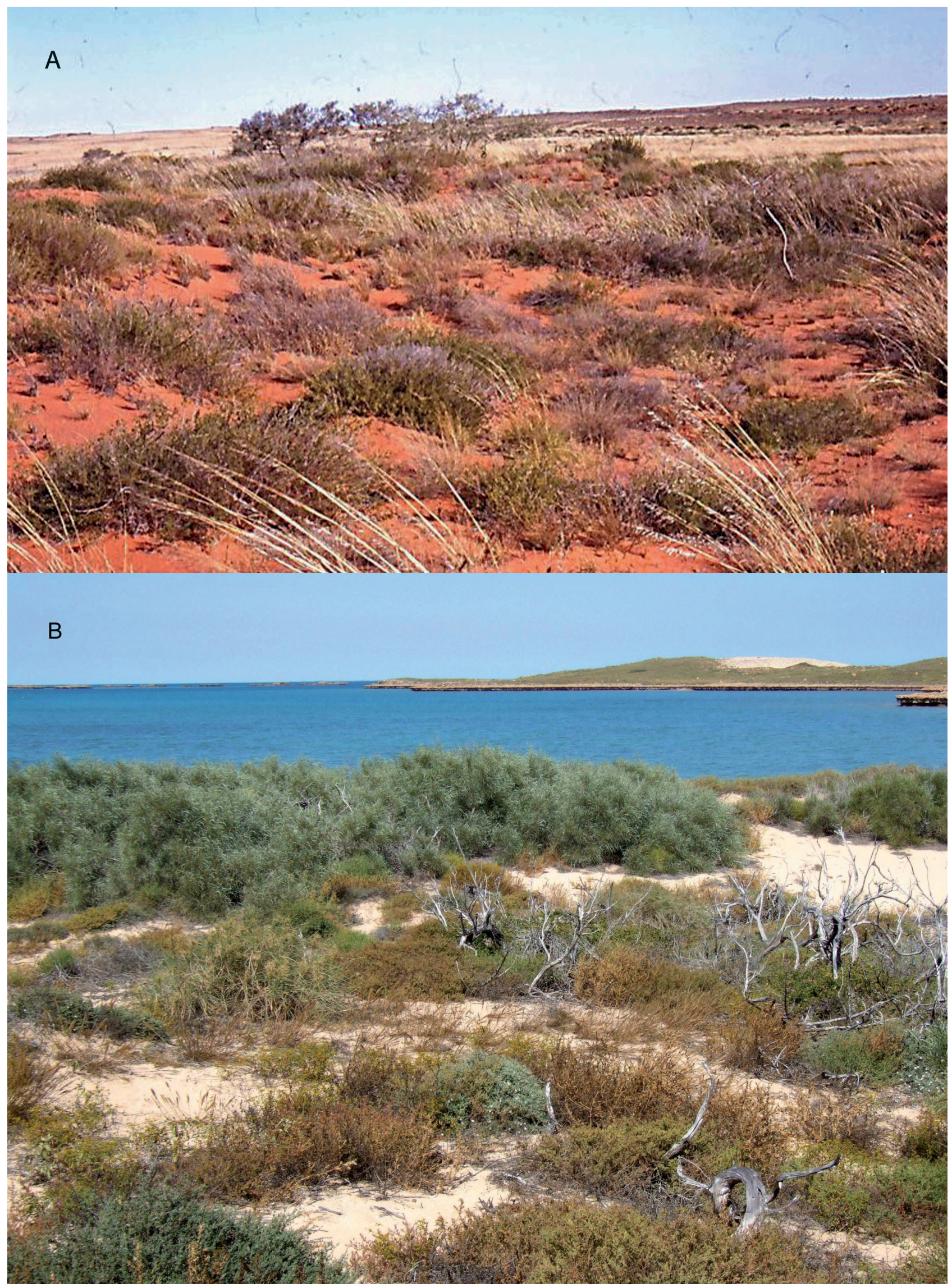

FIGURE 7 Contrasting sandy substrates reflect the subtle dorsal colour variation in Aprasia rostrata from the $(A)$ inland red sand dunes near Bullara Homestead and (B) coastal white sand dunes on Hermite Island (B. Maryan). 
in subocular position (v. second) and a more rounded rostrum in dorsal and lateral view (v. more pointed).

Aprasia rostrata differs from $A$. clairae in having a larger adult size (SVL up to $126 \mathrm{~mm} \mathrm{v}$. up to $90 \mathrm{~mm}$ ) and in both sexes the mean ventral and vertebral scale counts are significantly higher in $A$. rostrata than in $A$. clairae (183/179 v. 152/143).

Aprasia rostrata differs from $A$. repens in having 14 midbody scale rows (v. 12) and colouration, by having dark flecking under the head and along the ventral surface (v. whitish, often yellow in life under the head, occasionally marked with lines of short dashes along the ventral surface). In addition, in both sexes the mean ventral and vertebral scale counts are significantly higher in $A$. rostrata than in $A$. repens (183/179 v. $135 / 132)$ reflecting its more elongate-bodied form.

Aprasia haroldi, A. clairae and A. repens are all allopatric to $A$. rostrata (Maryan et al. 2013). All other Western Australian species differ from A. rostrata: with $A$. picturata and $A$. smithi having black heads (v. no black head) and A. inaurita, A. pulchella and A. striolata having rounded, blunt snouts with a free postocular (v. longer, more angular snout with postocular typically fused with fourth upper labial) (Storr et al. 1990; Wilson and Swan 2013).

\section{REMARKS}

Aplin and Smith (2001: 70) referred a specimen (WAM R61454) from the coastal sands of the North West Cape mainland to $A$. rostrata and posited that true fusca might be restricted to the inland sand dunes from the Bullara area. Colouration formed the basis for distinguishing $A$. $r$. fusca from A. r. rostrata (Storr 1979: 136-37) in which four specimens representing fusca from the North West Cape were compared to only two individuals of rostrata from Hermite Island that had been in preservative for considerable time. In the 'Key to Species of Aprasia' by Storr et al. (1990: 105) the diagnostics separating the two species state that 'four dark lines on back and a densely flecked venter with dark brown' as diagnostic for fusca and 'no dark lines on back and a white venter' as diagnostic for rostrata.

In this study, we examined a larger sample size of individuals from both coastal and inland localities, including recently collected material from the Montebello Islands and Barrow Island (see Appendix) and found no consistent trend in colour/pattern that corresponded to any diagnosable difference between the mainland and island populations of $A$. rostrata. Our observations suggest the degree of dark pigmentation on the lateral and ventral surfaces in combination with the intensity of lines on the dorsal surfaces are variable, and are arguably influenced by the subtly different substrates inhabited by these highly fossorial lizards. Individuals from the coastal sands of the mainland are as light in general appearance as those from the offshore islands, with slightly darker individuals occurring on inland sand dunes (Figure 5), a phenomenon regularly observed in other fossorial reptiles such as Aprasia smithi and Lerista planiventralis (B. Maryan and B.G. Bush pers. obs.).

\section{Aprasia litorea sp. nov.}

\section{Gnaraloo Worm Lizard}

Figures 8-10, 12

urn:Isid:zoobank.org:act:522E47F0-DA0E-4973-88FAA34850C5EB99

\section{MATERIAL EXAMINED}

\section{Holotype}

Australia: Western Australia: male, $1 \mathrm{~km} \mathrm{~S}$ of

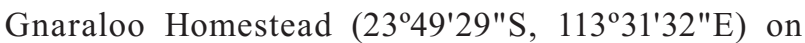
20 June 2000 by B. Maryan and B.G. Bush (WAM R141605).

\section{Paratypes}

Australia: Western Australia: 1 male, $9 \mathrm{~km}$ NE of Cape Cuvier $\left(24^{\circ} 11^{\prime} \mathrm{S}, 113^{\circ} 27^{\prime} \mathrm{E}\right)$, (WAM R116614); 1 female, $0.5 \mathrm{~km} \mathrm{~S}$ of Gnaraloo Homestead (234' S, 113 ${ }^{\circ} 32^{\prime} \mathrm{E}$ ), (WAM R116656); 1 female, $7 \mathrm{~km}$ SSW of Gnaraloo Homestead (23⒌'S, $\left.113^{\circ} 29^{\prime} \mathrm{E}\right)$, (WAM R116660); 1 male, Cape Cuvier $\left(24^{\circ} 09^{\prime} 54^{\prime \prime S}\right.$, $113^{\circ} 26^{\prime} 58^{\prime \prime E}$ ), (WAM R141606); 2 males, 1 female, $18 \mathrm{~km} \mathrm{SSE}$ of Quobba Homestead (24\%33'13"S, $\left.113^{\circ} 28^{\prime} 27^{\prime \prime E}\right)$, (WAM R151305-07).

\section{DIAGNOSIS}

A small (SVL up to $98 \mathrm{~mm}$ ) and very slender-bodied member of the $A$. repens species-group with 12 midbody scales, 162-170 ventral scales, 158-168 vertebral scales, five upper labials with first anteriorly fused to nasal, condition of nasal suture variably contacting prefrontal or second upper labial, postocular fused with fourth upper labial, and simple colouration of longitudinal lines of brownish streaks on a yellowish-brown dorsum with a densely flecked ventral surface.

\section{DESCRIPTION OF HOLOTYPE}

Head narrow, not wider or narrower than the body; no obvious tympanic aperture; snout long and rounded in dorsal profile, strongly projecting and moderately angular in lateral profile, but not sharp-edged, forming very distinct undershot lower jaw; eyes noticeably large on head positioned above third upper labial; nostril positioned anteriorly in nasal; body and tail very slender and round in cross-section; no vestiges of forelimbs externally; hindlimbs visible as very small triangular flaps at lateral extremes of vent; post-cloacal spurs evident as very small protrusion opposite triangular flaps; tail short with regenerated round tip.

Head scales smooth; large rostral rounded anteriorly, slightly longer than wide, visible from above with posterior point penetrating nasals; nasals large and in broad contact, angled posteriorly behind rostral; nasal fused anteriorly and forming suture with first upper labial; nasal suture originates from anterior border of second upper labial on left side, angled very slightly downwards to terminate at centre of nostril, forming 
A

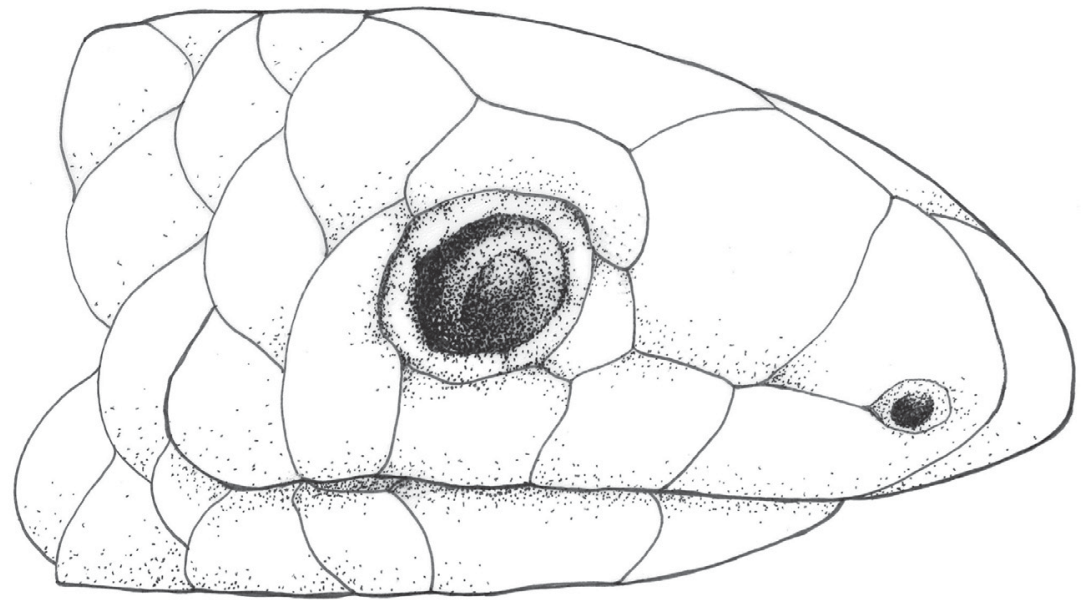

B

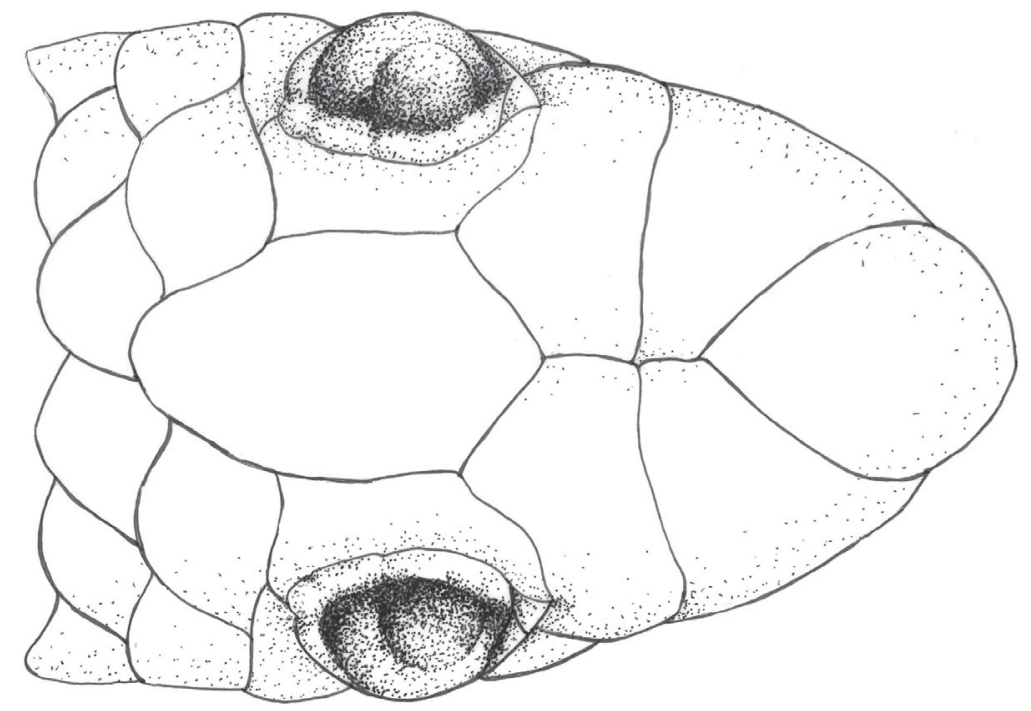

FIGURE 8 Head scalation of Aprasia litorea holotype (WAM R141605) in (A) lateral and (B) dorsal views.

short contact between nasal and second upper labial; on the right side, suture originates from prefrontal forming short contact with first upper labial, nasal suture not visible from above; prefrontals large and in broad contact, and in broad contact with second upper labial; frontal hexagonal, longer than wide and slightly rounded posteriorly; 1 large supraocular above full width of eyes in contact with preocular; 1 small preocular, much higher than wide, in broad contact with second upper labial and in short contact with third upper labial; 5 upper labials, second higher than third with equal width, fourth fused to postocular and fifth the smallest. General form of head and details of scalation illustrated in Figure 8.

Body scales, smooth and shiny, non-imbricate, homogeneous, and arranged in parallel longitudinal rows; ventral scales not noticeably wider than the adjacent body scales.

\section{Colouration}

In life (Figure 9), head yellowish-brown, variegated with dark brown on sides and on dorsal aspect of rostral and nasal scales. Dorsal surface yellowish-brown, more uniform anteriorly merging to greyish on tail. Two vague, longitudinal lines of brownish streaks (passing through centres of paravertebral scales) extend from behind head, gradually becoming continuous and increasing to multiple lines on tail. The outermost lines of laterodorsal streaks more continuous and not clearly demarcated from a silvery-grey lateral surface, broadly edged and centrally streaked with dark brown. Ventral surface (including under head) densely-flecked with dark brown, becoming darker towards vent. Ventral surface of tail light yellow and regenerated portion greyish with dark brown flecks.

In preservative (Figure 10), the yellowish-brown colouration on dorsal surface becomes cream. Dark 


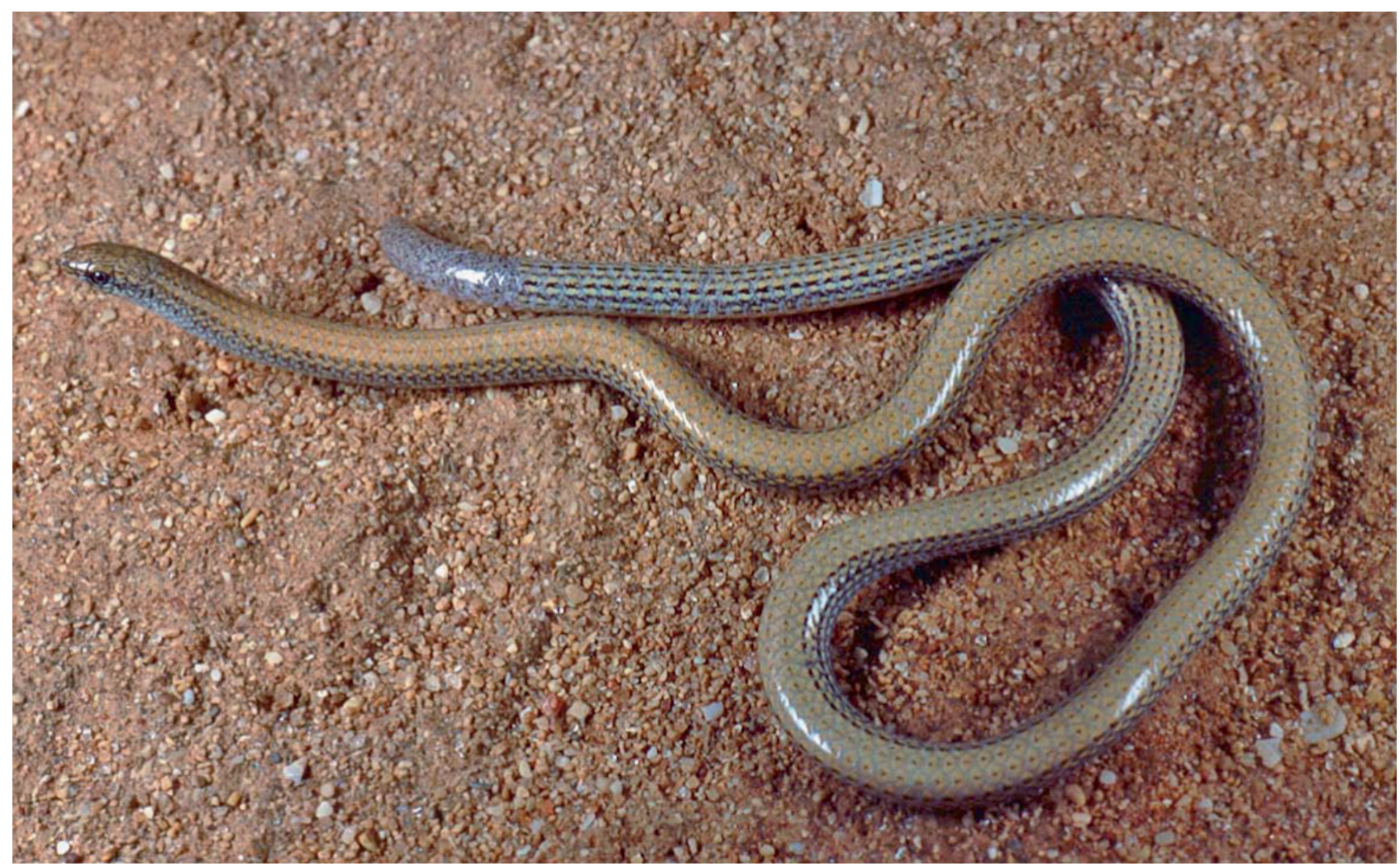

FIGURE 9 Holotype (WAM R141605) of Aprasia litorea, photographed in life (B. Maryan).

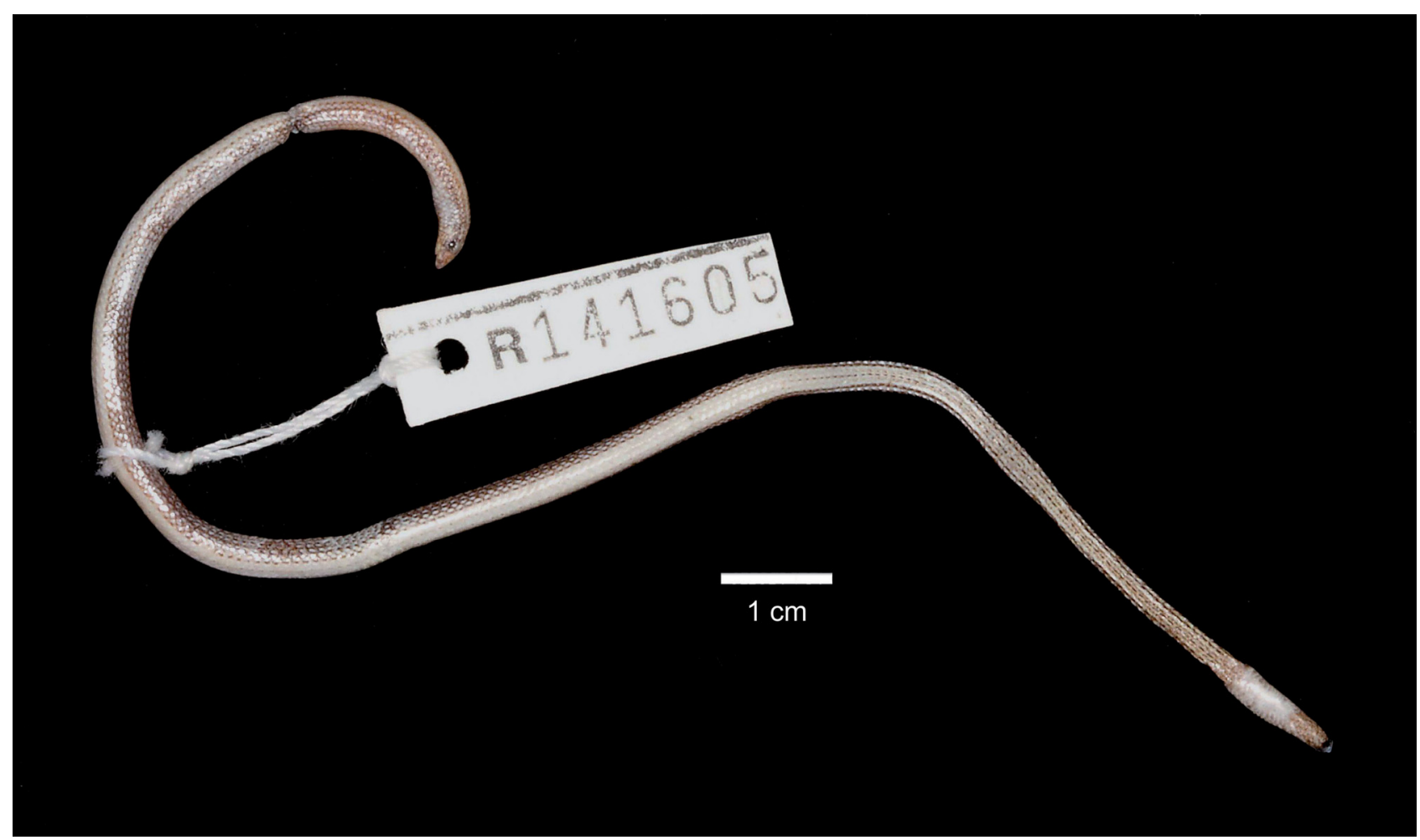

FIGURE 10 Preserved holotype of Aprasia litorea (WAM R141605). 
pigment on lateral and ventral surfaces, including lines of streaks along tail, is more prominent.

\section{Details of holotype}

Measurements in $\mathrm{mm}$. SVL -90 , TailL 43 regenerated (47\% of SVL), HeadD - 1.8, HeadL - 2.6, HeadW - 1.7, $\mathrm{RL}-0.7, \mathrm{RW}-0.6, \mathrm{SnL}-1.5$, EyeW $-0.8, \mathrm{Mbs}-12$, Vent -164 , Vert -160 .

\section{VARIATION}

Table 1 presents the ranges of the characters counted and measured for $A$. litorea. The paratypes are similarly coloured to the holotype in life and in preservative, except that the two smallest individuals, WAM R141606 (SVL $60 \mathrm{~mm}$ ) and WAM R151307 (SVL $51 \mathrm{~mm}$ ) are strongly variegated with dark brown on the head. The original tail of WAM R151306 is distinctly yellowish on both dorsal and ventral surfaces.

Storr et al. (1990: 106) noted the variation in $A$. fusca with the nasal suture originating from either the prefrontal or second upper labial that is similarly recorded in $A$. litorea as the following conditions: suture contacts prefrontal on both sides in WAM R116656; suture contacts second upper labial on both sides in WAM R116614, WAM R116660 and WAM R151305. As for the holotype, both conditions are present in WAM R141606 and WAM R151306. The nature of the nasal suture in WAM R151307 is different again connecting the suture between the first and second upper labials in such a position that these two labials, nasal and prefrontal meet.

\section{ETYMOLOGY}

The specific name is from the Latin adjective litoreus, meaning of the seashore, referring to the coastal distribution of the species.

\section{DISTRIBUTION}

Aprasia litorea is known from an area west of Lake Macleod extending north to Gnaraloo and south to Quobba Stations (Figure 4). The entire region is managed for pastoral purposes without any protected areas set aside for the conservation of flora and fauna. Further surveys are required at optimum times to the north and south of the known collection sites to determine whether this species is distributed more widely in the area.

\section{HABITAT}

The holotype was captured when it was raked (using a 3-prong cultivator) from inside a sand hillock stabilised by vegetation on white sand dunes near the coast. The paratypes have been variously collected in the same manner including beneath leaflitter and decaying stumps and logs embedded in the sand. The species is known to occupy a corridor (c. 1-10 km wide) along the coast consisting largely of white sand dunes or white to pink sandplains, vegetated mainly on the coast with littoral plants as Spinifex longifolius, Nitraria schoberi,
Scaevola crassifolia and Acanthocarpus preissii (Figure 11), gradually changing inland to denser and more varied assemblages with Acacia coriacea and other wattles, and hummock grasslands of Triodia (Storr and Harold 1984).

\section{COMPARISONS WITH OTHER SPECIES}

Aprasia litorea will be compared first with A. rostrata, the species with which it is most similar to in general aspects of body size, colouration and scalation, then with each of the geographically distant species with which it shares important characters.

Aprasia litorea differs from $A$. rostrata in having 12 midbody scale rows (v. 14), having a smaller adult size (SVL up to $98 \mathrm{~mm}$ v. up to $126 \mathrm{~mm}$ ) and in both sexes the mean ventral and vertebral scale counts are significantly lower in $A$. litorea than in $A$. rostrata (Table 1). A subtle but consistent difference concerns the demarcation between the outermost lines of the laterodorsal streaks with the lateral pattern: in A. litorea the demarcation is not clear with streaks mostly merging with lateral pattern, typically only the two lines of the paravertebral series are present, while in A. rostrata there is a clear gap between the lines of streaks and the lateral pattern, typically forming four lines that include the paravertebral series (Figure 12). In addition, both sexes of $A$. litorea appear more slender in build than in $A$. rostrata and have on average a slightly shorter head and snout (Table 1).

Aprasia litorea differs from $A$. haroldi in having 12 midbody scale rows (v. 14), 5 upper labials (v. 4), postocular fused to fourth upper labial (v. fused to third) and third upper labial in subocular position (v. second) and a more rounded rostrum in dorsal and lateral view (v. more pointed).

Aprasia litorea differs from A. clairae in having 12 midbody scale rows (v. 14), having a larger adult size (SVL up to $98 \mathrm{~mm}$ v. up to $90 \mathrm{~mm}$ ) and in both sexes the mean ventral and vertebral scale counts are significantly higher in A. litorea than in A. clairae (165/162 v. 152/143).

Aprasia litorea shares with $A$. repens 12 midbody scale rows, however differs in having a smaller adult size (SVL up to $98 \mathrm{~mm}$ v. up to $126 \mathrm{~mm}$ ) and having a colouration of dense dark flecking under the head and along the ventral surface (v. whitish, often yellow in life under the head, occasionally marked with lines of short dashes along the ventral surface). In addition, in both sexes the mean ventral and vertebral scale counts are significantly higher in A. litorea than in A. repens (165/162 v. 135/132) reflecting its more elongate-bodied form.

Aprasia haroldi, A. clairae and A. repens are all allopatric to $A$. litorea. All other Western Australian species differ from $A$. litorea: with $A$. picturata and A. smithi having black heads (v. no black head) and $A$. inaurita, A. pulchella and A. striolata having rounded, blunt snouts with a free postocular (v. longer, more 


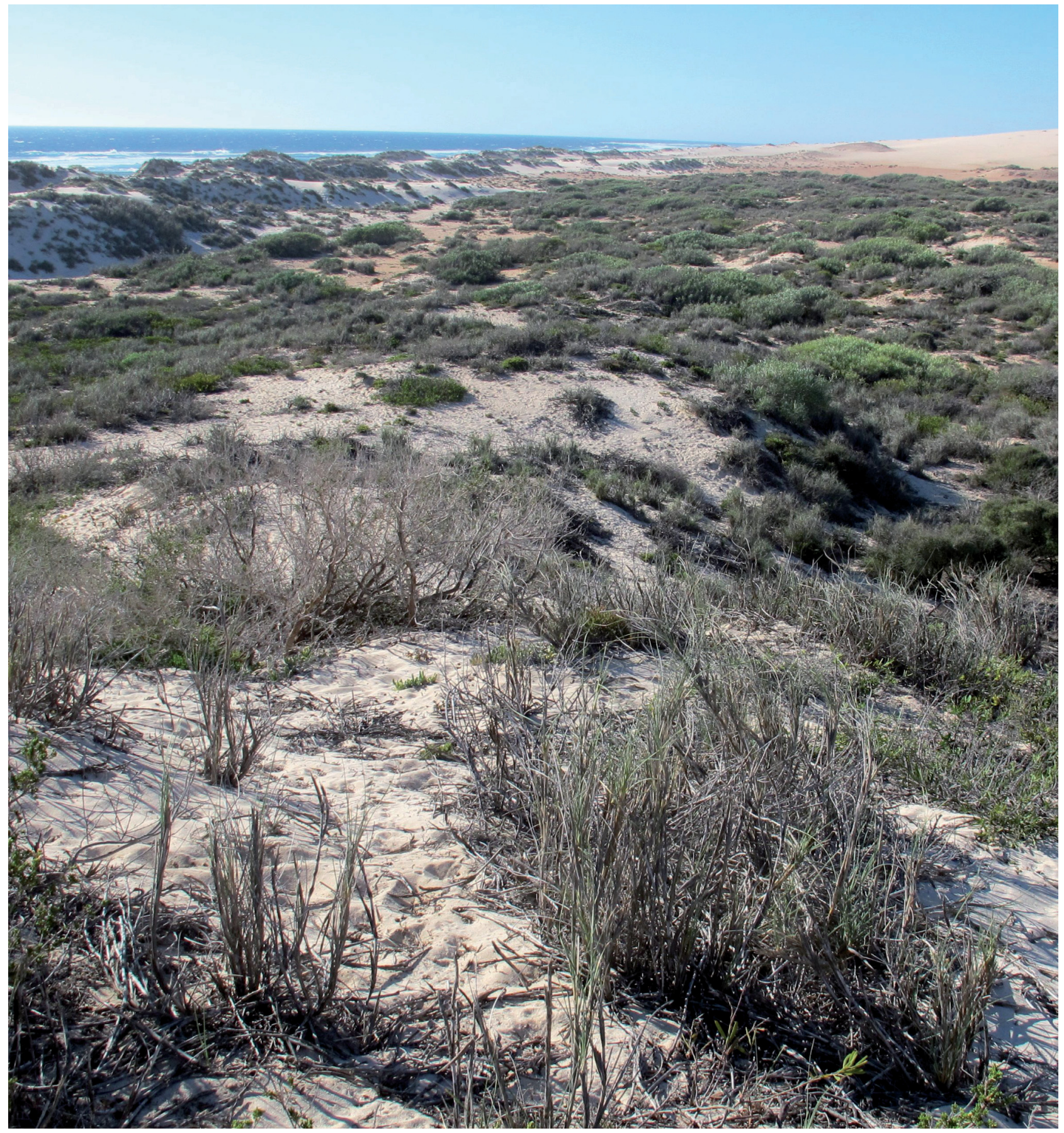

FIGURE 11 The habitat of Aprasia litorea, coastal low vegetation on sand dunes at Gnaraloo Homestead, Western Australia (B. Maryan).

angular snout with postocular fused with fourth upper labial).

\section{REMARKS}

Aprasia litorea was originally thought to represent a southern population of $A$. fusca when first collected during herpetofaunal surveys (Storr and Harold 1984). In Storr et al. 1990, the species account for A. fusca (incorporating $A$. litorea) included the statement 'usually 14 (occasionally 12) midbody scale rows' but without reference to a specific population. We examined all Western Australian Museum specimens of A. rostratal northern 'fusca' (Appendix and type lists in Taxonomy section) to determine the extent of variation in this character following exclusion of $A$. litorea. In the 27 specimens examined by us, we found no individual variation away from the conditional state of 14 midbody scale rows. Therefore, we believe the reference by Storr et al. (1990) to individuals with 12 midbody scale rows in $A$. fusca was in specific reference to specimens from the Lake Macleod region referred herein to A. litorea. 


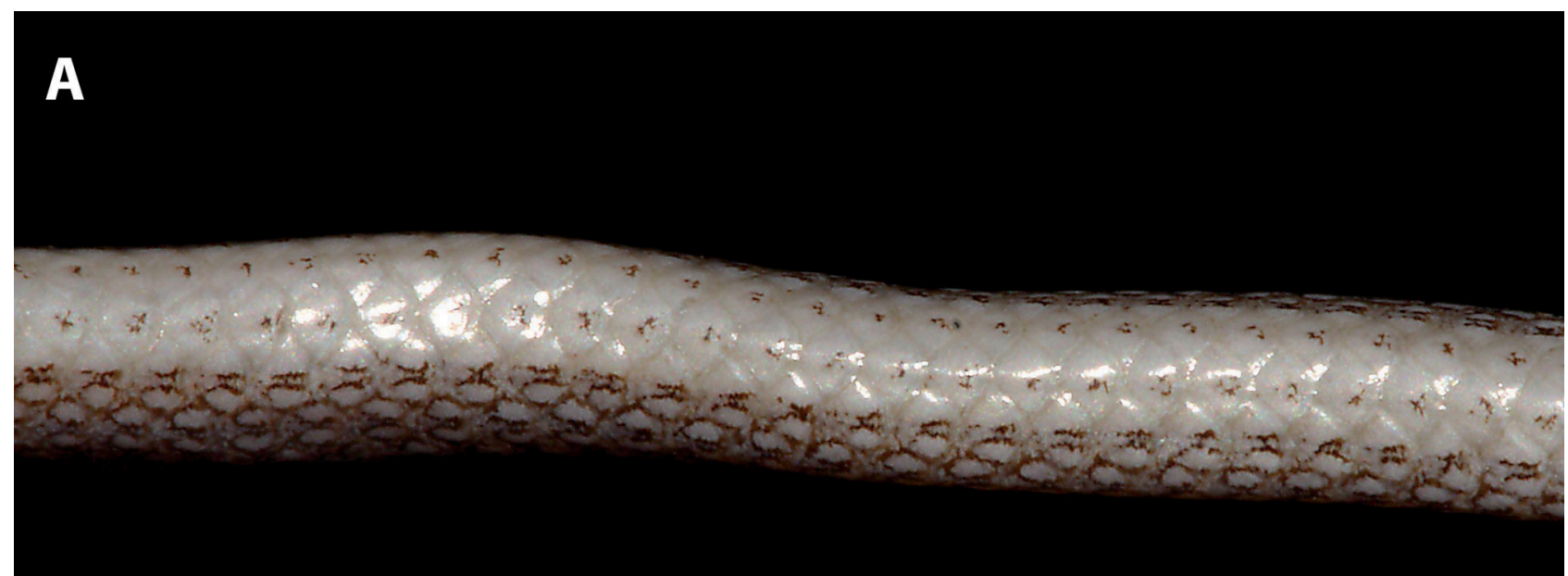

$1 \mathrm{~mm}$

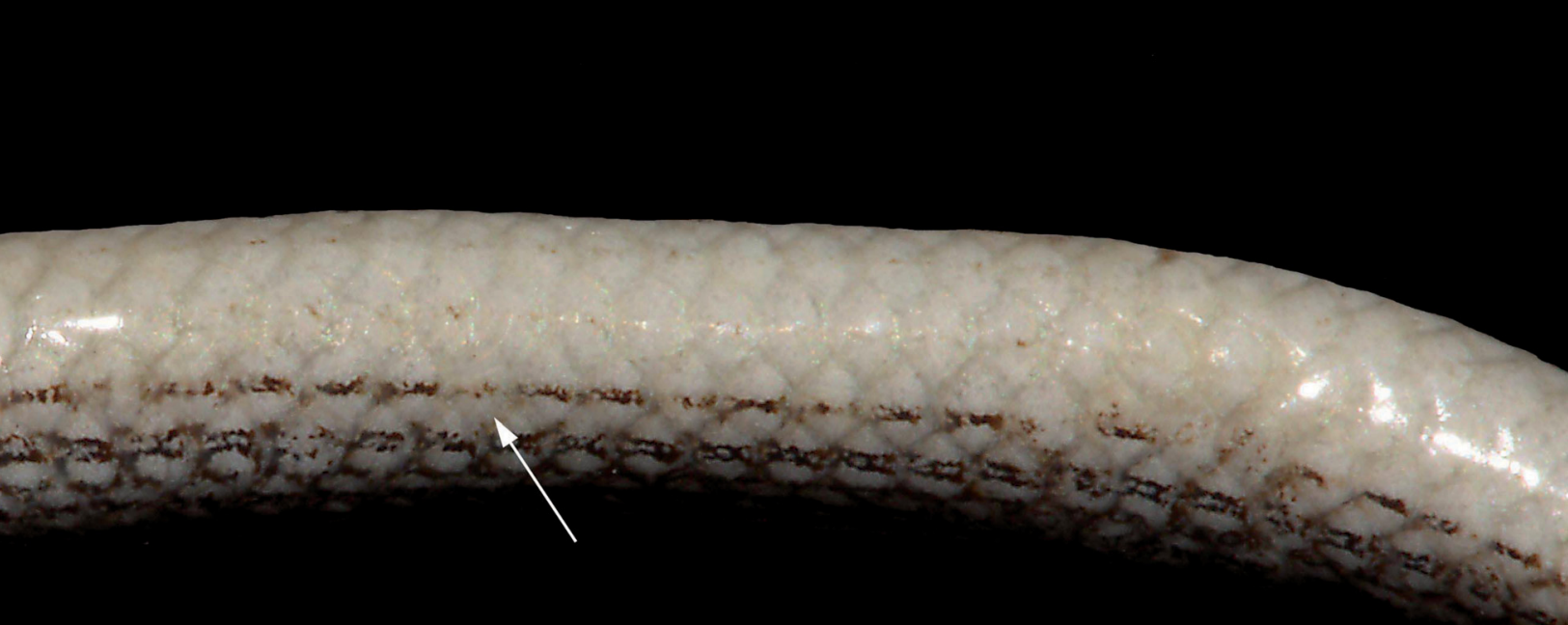

B

FIGURE 12 Dorsal view of (A) Aprasia litorea (WAM R151306) showing no clear demarcation between laterodorsal streaks and lateral surface, and (B) A. rostrata (WAM R153828), showing clear gap, indicated by arrow.

Aprasia repens appears to be the only species of Aprasia that exhibits rare intraspecific variation in midbody scale row counts Kluge (1974: 63).

McKenzie et al.'s (2000: 344) listing of Aprasia sp. aff. fusca is herein referred to A. litorea and Wilson and Swan (2013: 139) illustrate $A$. litorea as $A$. fusca from Gnaraloo Station. The only other reptile that shares a similar known distribution to $A$. litorea is the skink Lerista haroldi (Storr 1983), although McKenzie et al. (2000: 344) list a morphologically and allozymically distinctive population of Ctenotus hanloni that could also be restricted to the area west of Lake Macleod.

\section{DISCUSSION}

The present study has clarified the taxonomic relationships between $A$. fusca and A. rostrata and identified an additional member of the $A$. repens species-group as defined by Storr et al. (1990). Aprasia litorea from the coastal sands and adjacent sand plains west of Lake Macleod is a close relative of $A$. repens, the latter occurring throughout southwestern Western Australia and itself a composite taxon requiring further investigation. The geographic ranges of mainland $A$. rostrata and $A$. litorea appear to be allopatric, with current records suggesting a gap of more than $120 \mathrm{~km}$ between populations. These species are strongly differentiated genetically and they differ morphologically in subtle features of colouration (most notably the longitudinal lines of streaks on the dorsal surface) and in meristic characters that include the number of midbody scale rows, ventrals and vertebral scales. Considering the area between the known ranges of $A$. rostrata and $A$. litorea is poorly surveyed it should 
be investigated to determine whether either species exist in the intervening zone. The most northerly distributed species of Aprasia in Australia, A. rostrata has disjunct occurrences on sand dunes and plains of the North West Cape and on the Montebello Islands and Barrow Island off the Pilbara coast, reflecting the similarities in flora and fauna between these two areas (Keighery and Gibson 1993; Baynes and Jones 1993; Kendrick 1993) as well as their shared geological history. During periods of lowered sea level through the late Pliocene and Pleistocene, each of these areas formed rocky plateaux on a sandy, emergent continental shelf (Veth et al. 2007).

The $A$. repens species-group as defined by Storr et al. (1990) is endemic to Western Australia and particularly diverse in coastal sands and adjacent sand plains between Perth and the North West Cape. Aprasia repens as currently defined, is the most widespread species occurring throughout southwestern Western Australia, while the uniquely coloured A. picturata and A. smithi, occur mostly inland on harder (often stony) soils (Smith and Henry 1999; Wilson and Swan 2013). The remaining Australian Aprasia species, recognised on morphological (Kluge 1974) and molecular criteria (Jennings et al. 2003; Maryan et al. 2013; this study) have geographic distributions that range across southern Australia (excluding Tasmania). The A. repens speciesgroup is the most diverse clade in the genus, however, with a total of seven of the thirteen known Australian species, but as noted previously (Aplin and Smith 2001; Maryan et al. 2013), the taxonomic diversity in the group is incompletely documented with further species awaiting description.

Compared to other fossorial species such as skinks of the genus Lerista and the blind or worm snakes (Ramphotyphlops), instances of sympatry between species of Aprasia are infrequently recorded. One exception is the widespread species $A$. repens which overlaps in distribution with $A$. pulchella on the Darling Range east of Perth and with A. striolata on the southern coast (Bush et al. 2007). All appear to feed on very small ant eggs and larvae and occur mostly in coastal and near coastal sands or inland on sand plains and stony soils. Although Aprasia may appear to be lizard equivalents of the blind or worm snakes (Webb and Shine 1994), which similarly spend most of their life underground, these fossorial snakes occupy a much wider variety of substrates, are more geographically widespread and feed on the eggs and larvae of a much greater variety and size of ants. This has resulted in their comparative morphological divergence, which would reduce any competitive exclusion between the two groups, allowing them to exist sympatrically.

For highly cryptic fossorial reptiles such as Aprasia, it often requires a considerable length of time conducting trapping programs to reveal their presence (How and Shine 1999). During the course of the Carnarvon Basin Survey, only a single live capture of $A$. litorea was made using pit-trapping (Rolfe and Mckenzie 2000) and over two weeks using the same technique on the
Montebello Islands no specimens of $A$. rostrata were found (Burbidge et al. 2000). In addition to this, $A$. rostrata was only recently recorded for the first time on the historically well collected and visited Barrow Island (Butler 1970; Smith 1976; Bamford 2002). This cryptic lifestyle means their basic biology is virtually unstudied, therefore any inferences on population size, declines or seasonal trends related to breeding and feeding are purely speculative (Maryan et al. 2013).

Many of the current listings of the 26 'threatened (including $A$. rostrata)' and 48 'priority' reptile species in Western Australia comprise small, cryptic varieties with apparent localised distributions (e.g. Aprasia, Lerista and Ramphotyphlops). These listings include several species and/or subspecies with unresolved taxonomies (e.g. L. praefrontalis) and those still only known from a single specimen (e.g. L. bunglebungle, $L$. quadrivincula and $R$. longissimus). Adding to this are the recent descriptions of cryptic, new species in areas subject to high anthropogenic disturbance (Kay and Keogh 2012; Doughty and Oliver 2013; Maryan et al. 2013). Wildlife conservation and protective legislation should be based on sound ecological principles and knowledge of wild populations (Ehmann and Cogger 1985). Currently, our knowledge is inadequate for many of these species, and there is a need to rationalise the criteria and listings, as field and life history studies (including targeted faunal surveys) should be considered a prioritised measure. There is much work to be done if we are to address the conservation, management and taxonomic issues relating to Western Australia's endangered herpetofauna.

\section{ACKNOWLEDGEMENTS}

We thank K. Aplin for initiating the study and stimulating our interest in the taxonomy of Western Australian Aprasia, and P. Doughty and M. Harvey for providing helpful advice throughout the study including insightful comments on earlier drafts of the manuscript. We thank D. Algaba, R. Browne-Cooper, G. Harold and $\mathrm{R}$. Teale for collecting important specimens that were crucial for this study. We thank R. How for the statistical analysis. We thank C. Stevenson, A. Heidrich and R. Somaweera for the preparation of some figures. D. Robinson provided helpful technical assistance with figures. We are extremely grateful to the $\mathrm{H}$. and M. Butler Fund for generously funding our trip to the Montebello Islands in 2006. The success of this trip was made possible due to the support of Morgan Pearls, in particular M. Hood and R. Stuart who coordinated logistics from Exmouth. Special thanks go to the Faraday Pearl II crew for their assistance and especially to W. O'Donnell (the skipper) who transported us to and from islands and K. 'Princess' Farmer (the cook) for providing us with great sustenance. The Department of Parks and Wildlife authorised this trip under permits SF005246 and CE001372. For helpful comments on drafts of the manuscript we thank the two anonymous referees. 


\section{REFERENCES}

Anderson, M.J., Gorley, R.N. and Clarke, K.R. (2008). PERMANOVA+ for PRIMER: Guide to Software and Statistical Methods. PRIMER-E Ltd: Plymouth.

Aplin, K.P. and Smith, L.A. (2001). Checklist of the frogs and reptiles of Western Australia. Records of the Western Australian Museum Supplement 63: 51-74.

Bamford, M.J. (2002). The Terrestrial Vertebrate Fauna of Barrow Island in relation to the Gorgon Gas Development. Unpublished Report to Bowman Bishaw Gorham. Bamford Consulting Ecologists: Perth.

Baynes, A. and Jones, B. (1993). The mammals of Cape Range peninsula, north-western Australia, Pp. 207-225 in W.F. Humphreys (ed.) The Biogeography of Cape Range, Western Australia. Records of the Western Australian Museum Supplement 45.

Burbidge, A.A., Blyth, J.D., Fuller, P.J., Kendrick, P.G., Stanley, F.J. and Smith, L.A. (2000). The terrestrial vertebrate fauna of the Montebello Islands, Western Australia. CALM Science 3: 95-107.

Bush, B., Maryan, B., Browne-Cooper and Robinson, D. (2007). Reptiles and Frogs in the Bush: Southwestern Australia. University of Western Australia Press: Perth.

Butler, W.H. (1970). A summary of the vertebrate fauna of Barrow Island, W.A. Western Australian Naturalist Journal 11: $149-160$.

Clarke, K.R. and Gorley, R.N. (2006). PRIMER v6: User Manual/Tutorial. PRIMER-E Ltd: Plymouth.

Cogger, H.G., Cameron, E.E., Sadlier, R.A. and Eggler, P. (1993). The Action Plan for Australian Reptiles. Australian Nature Conservation Agency: Canberra.

Doughty, P. and Oliver, P.M. (2013). Systematics of Diplodactylus (Squamata: Diplodactylidae) from the southwestern Australian biodiversity hotspot: redefinition of $D$. polyophthalmus and the description of two new species. Records of the Western Australian Museum 28: 44-65.

Ehmann, H. and Cogger, H. (1985). Australia's endangered herpetofauna: a review of criteria and policies. Pp 435-447 in G. Grigg, R. Shine and H. Ehmann (eds.) Biology of Australasian Frogs and Reptiles. Royal Zoological Society of NSW: Sydney.

Gray, J.E. (1839). Catalogue of the slender-tongued saurians, with descriptions of many new genera and species (continued). Annals and Magazine of Natural History series 1, 2: 331-337

Hill, F.L. (1955). Notes on the natural history of the Monte Bello Islands. Proceedings of the Linnaean Society of London 165: 113-124.

Jennings, W.B., Pianka, E.R. and Donnellan, S. (2003). Systematics of the lizard family Pygopodidae with implications for the diversification of Australian temperate biotas. Systematic Biology 52: 757-780.

Kay, G.M. and Keogh, J.S. (2012). Molecular phylogeny and morphological revision of the Ctenotus labillardieri (Reptilia: Squamata: Scincidae) species group and a new species of immediate conservation concern in the southwestern Australian biodiversity hotspot. Zootaxa 3390: $1-8$.

Keighery, G. and Gibson, N. (1993). Biogeography and composition of the flora of the Cape Range peninsula, Western Australia, Pp. 193-206 in W.F. Humphreys (ed.) The Biogeography of Cape Range, Western Australia. Records of the Western Australian Museum Supplement 45.

Kendrick, P.G. (1993). Biogeography of the vertebrates of the Cape Range peninsula, north-western Australia, Pp. 207-225 in W.F. Humphreys (ed.) The Biogeography of Cape Range, Western Australia. Records of the Western Australian Museum Supplement 45.

Kluge, A.G. (1974). A taxonomic revision of the lizard family Pygopodidae. Miscellaneous Publications of the Museum of Zoology, University of Michigan No. 152: 1-72.

Maryan, B. and Bush, B. (2007). Rediscovery of Aprasia rostrata on the Montebello Islands, Western Australia. Western Australian Naturalist Journal 25: 247-251.

Maryan, B., How, R.A. and Adams, M. (2013). A new species of the Aprasia repens species-group (Squamata: Pygopodidae) from Western Australia. Records of the Western Australian Museum 28: 30-43.

McKenzie, N.L., Rolfe, J.K., Aplin, K.P., Cowan, M.A. and Smith, L.A. (2000). Herpetofauna of the southern Carnarvon Basin, Western Australia. Records of the Western Australian Museum Supplement 61: 335-360.

Parker, H.W. (1956). The lizard genus Aprasia: its taxonomy and temperature-correlated variations. Bulletin British Museum (Natural History) Zoology 3: 365-385.

Richardson, B.J., Baverstock, P.R. and Adams, M. (1986). Allozyme Electrophoresis: a Handbook for Animal Systematics and Population Studies. Academic Press: Sydney.

Richardson, J., Watson, G. and Kregor, G. (2006). The distribution of terrestrial vertebrate fauna in the Montebello Islands. CALM Science 5: 11-13.

Rolfe, J.K. and McKenzie, N.L. (2000). Comparison of methods used to capture herpetofauna: an example from the Carnarvon basin. Records of the Western Australian Museum Supplement 61: 361-370.

Smith, L.A. (1976). The reptiles of Barrow Island. Western Australian Naturalist Journal 13: 125-136.

Smith, L.A. and Henry, J. (1999). Aprasia picturata (Squamata: Pygopodidae), a new legless lizard from the interior of Western Australia. Journal of the Royal Society of Western Australia 82: 75-77.

Storr, G.M. (1979). Five new lizards from Western Australia. Records of the Western Australian Museum 8: 134-142.

Storr, G.M. and Hanlon, T.M.S. (1980). Herpetofauna of the Exmouth region, Western Australia. Records of the Western Australian Museum 8: 423-439.

Storr, G.M. (1983). Two new lizards from Western Australia (Genera Diplodactylus and Lerista). Records of the Western Australian Museum 11: 59-62.

Storr, G.M. and Harold, G. (1984). Herpetofauna of the Lake Macleod region, Western Australia. Records of the Western Australian Museum 11: 173-189.

Storr, G.M., Smith, L.A. and Johnstone, R.E. (1990). Lizards of Western Australia III Geckos \& pygopods. Western Australian Museum: Perth.

Veth, P., Aplin, K., Wallis, L., Manne, T., Pulsford, T., White, E. and Chappell, A. (2007). The Archaeology of Montebello Islands, North-West Australia: Late Quaternary foragers on an arid coastline. Archaeopress: Oxford UK.

Webb, J.K. and Shine, R. (1994). Feeding habits and reproductive biology of Australia pygopodids lizards of the genus Aprasia. Copeia 1994: 390-398.

Wilson, S. and Swan, G. (2013). A Complete Guide to Reptiles of Australia. Fourth Edition. New Holland Publishers: Chatswood.

MANUSCRIPT RECEIVED 11 SEPTEMBER 2013; ACCEPTED 25 NOVEMBER 2013 
APPENDIX Additional material examined. All locations are from Western Australia (WAM prefixes omitted). *Also included in the allozyme study. ^Allozyme study only.

A. clairae $^{\wedge} \mathrm{R} 127527,{ }^{\wedge} \mathrm{R} 156892,{ }^{\wedge} \mathrm{R} 156901$.

A. haroldi $^{\wedge} \mathrm{R} 135496$.

A. litorea *R116614, *R116656, *R116660.

A. pulchella ${ }^{\wedge} \mathrm{R} 80000,{ }^{\wedge} \mathrm{R} 132803,{ }^{\wedge} \mathrm{R} 135130-31$.

A. repens ${ }^{\wedge} \mathrm{R} 113330,{ }^{\wedge} \mathrm{R} 119919,{ }^{\wedge} \mathrm{R} 137457,{ }^{\wedge} \mathrm{R} 144612$, ^151695-96, ^R165961.

A. rostrata $\mathrm{R} 74951$ (female), Bullara Homestead ( $\left.22^{\circ} 41^{\prime} \mathrm{S}, 114^{\circ} 02^{\prime} \mathrm{E}\right)$; R110662 (male), Learmonth Air Weapons Range (22²5'04"S, 11345'50"E); *R116651 (female), $1 \mathrm{~km} \mathrm{NW}$ of Bullara Homestead $\left(22^{\circ} 41^{\prime} \mathrm{S}\right.$, $114^{\circ} 03^{\prime} \mathrm{E}$ ); *R116672 (female), $2 \mathrm{~km} \mathrm{~W}$ of Bullara Homestead $\left(22^{\circ} 41^{\prime} \mathrm{S}, 114^{\circ} 01^{\prime} \mathrm{E}\right)$; *R116882 (female), $21 \mathrm{~km} \mathrm{~N}$ of Bullara Homestead (22 $\left.{ }^{\circ} 29^{\prime} \mathrm{S}, 114^{\circ} 01^{\prime} \mathrm{E}\right)$; *R116914 (female), $2 \mathrm{~km} \mathrm{~W}$ of Bullara Homestead (22 $\left.41^{\prime} \mathrm{S}, 114^{\circ} 01^{\prime} \mathrm{E}\right)$; R130221 (female), $8 \mathrm{~km} \mathrm{~N}$ of
Exmouth (2152'12"S, 114 $07^{\circ} 01^{\prime \prime E}$ ); R141583 (male), 2 $\mathrm{km}$ W of Bullara Homestead (22040'20"S, $\left.114^{\circ} 00^{\prime} 52^{\prime \prime} \mathrm{E}\right)$; R142340, R142359 (females), Yardie Creek (22¹9'14"S, 1134' 50"E); R151725-27 (female, male, male), $1.5 \mathrm{~km}$ $\mathrm{W}$ of Bullara Homestead (22 $\left.41^{\prime} \mathrm{S}, 114^{\circ} 01^{\prime} \mathrm{E}\right)$; *R15382728 (male, female), $2 \mathrm{~km} \mathrm{NW}$ of Yardie Homestead

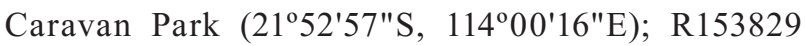
(female), Bullara Station (22 $2^{\circ} 3^{\prime} 26^{\prime \prime S}, 113^{\circ} 55^{\prime} 25^{\prime \prime E}$ ); R153830 (male), Bullara Station $\left(22^{\circ} 43^{\prime} 35^{\prime \prime S}\right.$, $113^{\circ} 58^{\prime} 32^{\prime \prime E}$ ); *R165984-85 (males), Trimouille Island (20²3'12"S, 115³3'04"E); *R165986-87 (males), Hermite Island $\left(20^{\circ} 29^{\prime} 36^{\prime \prime S}, 115^{\circ} 31^{\prime} 40^{\prime \prime E}\right)$; R173456

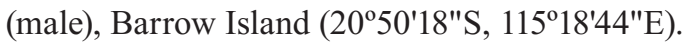

A. smithi ${ }^{\wedge} \mathrm{R} 116574,{ }^{\wedge} \mathrm{R} 116657$.

A. striolata $^{\wedge} \mathrm{R} 127524, \wedge \mathrm{R} 127528$. 